DOEICE-0.039
$1 / 1 / 22-99$

\title{
Geothermal Progress Monitor
}

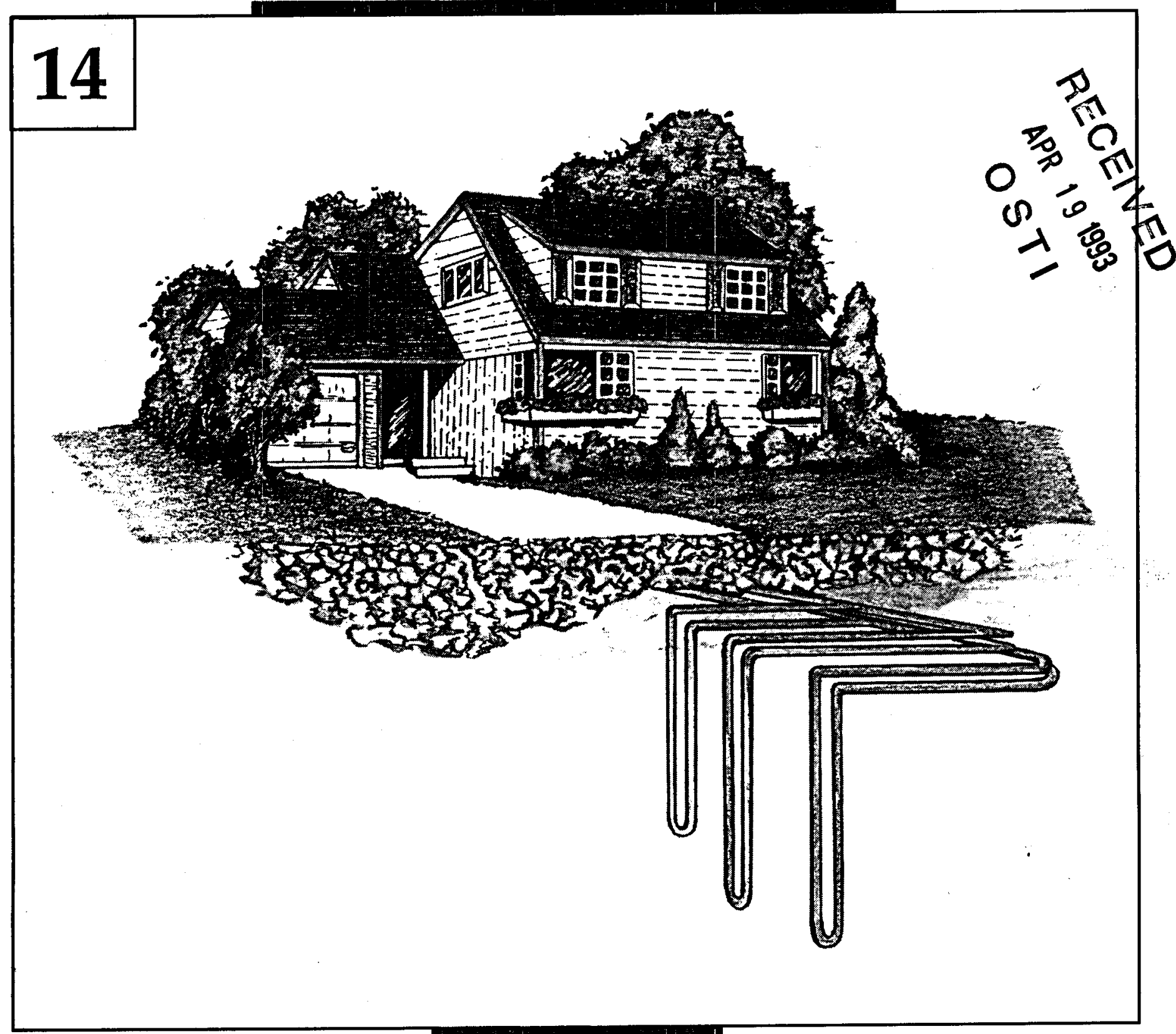

\section{December 1992}

\section{U.S. Department of Energy}

Assistant Secretary for Conservation and Renewable Energy

Geothermal Division 


\section{DISCLAIMER}

This report was prepared as an account of work sponsored by an agency of the United States Government. Neither the United States Government nor any agency Thereof, nor any of their employees, makes any warranty, express or implied, or assumes any legal liability or responsibility for the accuracy, completeness, or usefulness of any information, apparatus, product, or process disclosed, or represents that its use would not infringe privately owned rights. Reference herein to any specific commercial product, process, or service by trade name, trademark, manufacturer, or otherwise does not necessarily constitute or imply its endorsement, recommendation, or favoring by the United States Government or any agency thereof. The views and opinions of authors expressed herein do not necessarily state or reflect those of the United States Government or any agency thereof. 


\section{DISCLAIMER}

Portions of this document may be illegible in electronic image products. Images are produced from the best available original document. 
This report has been reproduced directly from the best available copy.

Available to DOE and DOE contractors from the Office of Scientific and Technical Information, P.O. Box 62, Oak Ridge, TN 37831; prices available from (615) 576-8401, FTS 626-8401.

Available to the public from the National Technical Information Service, U.S. Department of Commerce, 5285 Port Royal Rd., Springfield, VA 22161. 
DOE/CE- -0394

DE93 011709

\title{
Geothermal Progress Monitor
}

\section{Report No. 14}

\section{December 1992}

\author{
U.S. Department of Energy \\ Assistant Secretary for Conservation \\ and Renewable Energy \\ Geothermal Division \\ Washington, DC 20585
}

Prepared with the Assistance of Meridian Corporation, Alexandria, Virginia 
CONTENTS

Introduction .........

The Federal Beat $\ldots \ldots \ldots 3$

The Industry Scene . . . . 15

Financing $\ldots \ldots \ldots 21$

Development Status . . . . 23

Leasing and Drilling . . . 39

State and Local .......45

International $\ldots \ldots \ldots \ldots 5$

Technology Transfer . . . . . 57

Directory ........77

ILLUSTRATION: A ground source heat pump system that harnesses the Earth's natural geothermal energy to heat, cool, and provide hot water for private residences and larger buildings. (Photo courtesy of Missouri Department of Natural Resources, Division of Energy.l 
This issue of the Geothermal Progress Monitor, the 14th since its inception in 1980, highlights the anticipated rapid growth in the use of geothermal heat pumps and documents the continued growth in the use of geothermal energy for power generation, both in this country and abroad. In countries with a relatively large demand for new generation capacity, geothermal, if available, is being called on as a preferable alternative to the use of domestic or imported oil. On the other hand, in this country where current demand for new capacity is less, geothermal energy is commonly being put to use in small power generation units operating on the hot water resource.

The power plant tables in the section, DEVELOPMENT STATUS, list 19 announced hot water plants in the U.S. with a total capacity of over $550 \mathrm{MWe}$. With the exception of the Navy's plans for $160 \mathrm{MWe}$ at Fallon, Nevada, those of the Los Angeles Department of Water and Power for $100 \mathrm{MWe}$ at Coso, and the $\mathbf{5 0}$ MWe installation of True/Mid-Pacific in Hawaii, none of these plants will exceed $25 \mathrm{MWe}$, and most are in the 10-20 MWe range. This reflects the Nation's limited demand for new generating capacity and the need, in some cases, to prove a new reservoir before investing in larger plants. However, the expansion of the three Magma Power Co. plants at the Salton Sea -- Del Ranch, Elmore I, and Leathers I -- by 6 MWe each exemplifies the potential for growth in capacity as demand and field conditions permit.

The U.S. power plant tables also show that when the announced development is completed, 24 areas in six states, not all of which are designated Known Geothermal Resources Areas, will have geothermal plants. This geographic expansion is due in part to demonstration facilities at two locations in Oregon and at Surprise Valley in northern California to use the fluids of the Cascade Range, an as yet unexploited resource.

The INTERNATIONAL section describes the use of geothermal energy to satisfy large power demands in the Philippines and Indonesia. In fact, the government of the Philippines "now realizes that full development of its geothermal resources is the only alternative to the country's growing electric power requirements," according to an International Geothermal Association report in IGA News. As a result, the Philippines National Oil Co. will allot 68 percent of its total investments from 1992 to 1996 to geothermal projects. Similarly, Indonesia is pursuing an energy policy that reduces its dependence on oil as a primary source of energy; the country plans to increase its installed geothermal electric capacity from its current $142.5 \mathrm{MWe}$ to $430 \mathrm{MWe}$ by 1995 and 870 MWe by 2000 .

The recently enacted National Energy Policy Act of 1992 will provide the impetus for further development by independent power producers (IPPs) by exempting them from regulation by the Public Utility Holding Company Act. However, as Dr. John E. Mock, Director of the Geothermal Division of the Department of Energy, points out in the FEDERAL BEAT, geothermal energy can only take advantage of the doors being opened to IPPs when and where it meets the economic competition. "Thus," he said, "I see technology advancement as one of the key roles available to government to support increased geothermal power sales in a dynamic utility market. Technology improvement and innovation that translate into reduced costs are, therefore, our continuing research focus."

A major element of the Federal effort is $R \& D$ designed to reduce by 50 percent the up-front exploration and reservoir assessment costs required to obtain financing for geothermal power 
development. As described in the section, LEASING AND DRILLING, the current focus of achieving this objective is to determine if slimhole drilling can provide sufficient reservoir data to avoid costly productionsize exploration wells. Government contractors will join with industry in costsharing slimhole drilling at several locations, where reservoir parameters are already known, for direct comparison of the results of the two technologies.

The number of articles in this issue related to geothermal heat pumps and the number of entities interested in promoting their use underscore the growing importance of this technology. The benefits of GHPs to utilities as a demandside management (DSM) tool, to consumers through reduced utility bills, and to the nation through lower energy consumption are described in DEVELOPMENT STATUS, and their environmental benefits are discussed in FEDERAL BEAT. However, new regulatory mechanisms to encourage utility participation in DSM and cost reductions in installing GHPs are needed to accelerate market penetration. In July 1992, a congressional panel focused on the role of GHPs in the national energy picture. Also in July, a series of teleconferences on the benefits of GHPs was begun under the sponsorship of the GHP industry, the utility industry, and several Federal agencies, including DOE and EPA. (see TECHNOLOGY TRANSFER).

Another notable feature of GPM \# 14 is the emphasis on technology transfer. The TECHNOLOGY TRANSFER section now includes efforts, both in the U.S. and overseas, to bring new developments as they occur to users and decision-makers worldwide. The GPM itself is published by DOE's Geothermal Division as one of its many activities in technology transfer. These longstanding efforts were recognized by the Department of Energy in January 1992 with the presentation of a Lifetime Achievement Award in Technology Transfer to Dr. John E. Mock, the Division's Director. Announced by the Secretary of Energy, James D. Watkins, the award cited Mock's efforts "to intensify and accelerate the commercialization of high quality scientific and technological achievements from our national laboratories, and from research and development activities sponsored by the federal government." Dr. Mock also received the Geothermal Resources Council Special Achievement Award in October 1991 for transferring technology from national laboratories to industry. 


\section{ENERGY POLICY ACT OF 1992 PROVIDES NEW OPPORTUNITIES FOR INDEPENDENT POWER PRODUCERS}

The Energy Policy Act, signed into law on October 24, 1992, embraces and implements many of the actions recommended by the President in the National Energy Strategy. It is described by Energy Secretary James D. Watkins as "the most comprehensive and balanced energy legislation ever enacted [which] will bring new jobs, greater energy security, and a cleaner environment." "The Act," he said, "will stimulate domestic energy production, promote energy efficiency, increase competition in the electricity sector reducing consumer costs, and develop alternatives to imported oil."

A number of the Act's provisions appear favorable to geothermal development. Some of them are not directed specifically toward geothermal power per se, but are broad enough to encompass independent geothermal power producers along with other IPPs. These provisions include further deregulation of the IPP industry and a strong mandate for IPP access to transmission facilities. The first of these is accomplished by creating new entities known as "exempt wholesale generators" (EWGs) that may generate and sell power without the restrictions of the Public Utility Holding Company Act. Structuring project ownership to avoid triggering PUHCA regulation has long been considered a major impediment to IPPs, and the freedom granted by the Act is designed to encourage companies that are not electric utilities to get into the power generating business and compete to sell electricity to any utility that will buy it. Significantly, EWGs do not lose their status as qualifying facilities under the Public Utility Reçulatory Policies Act (PURPA), and its requirement for utilities to purchase the power of such facilities remains intact.

Perhaps one of the most important provisions of the Act for the geothermal power industry, as it is currently structured, continues another trend established in PURPA - i.e., affiliation of an EWG with a utility does not preclude the utility from purchasing power from the EWG if cognizant state regulators determine that such transactions meet certain criteria - e.g., that they will benefit consumers, are in the public interest, and would not provide the utility affiliate unfair competitive advantage.

Transmission access for EWGs is provided through authority granted to the Federal Energy Regulatory Commission (FERC) to order utilities, upon application by a qualified EWG, to provide wholesale transmission services under terms that would 1) permit the utility to recover all of its costs in connection with the transmission services, and 2) would not unreasonably impair the continued reliability of the affected electrical systems. While the legislation as passed omitted earlier language that left FERC no discretion to do otherwise, numerous observers, according to the publication Electric Power Alert, say that regardless of the change in wording, "mandated access will be the order of the day."

Other sections of the Energy Policy Act are designed specifically to promote growth in the use of geothermal energy and other renewable energy resources. However, implementation of these provisions is 
subject to the availability of appropriated funding which will require follow-on legislation.

A provision of the Act that could immediately impact the R\&D program, if funded, is the call for support of "demonstration and commercial application" projects that utilize high- and low-temperature geothermal energy and other renewable energy resources. DOE is required to solicit proposals for projects within nine months of enactment of the Act on the basis of advice provided by an Advisory Committee on Demonstration and Commercial Applications of Renewable Energy and Energy Efficiency Technologies. A total of $\$ 50$ million is authorized (not appropriated) for fiscal 1994.

In addition, subject to the availability of appropriations, DOE is directed to establish a "production incentive program for renewable energy" which would provide payments to "qualified renewable energy facilities" for a 10-year period at a cost of $1.5 \mathrm{c} / \mathrm{kWh}$, adjusted for inflation. Power plants using dry geothermal steam would not qualify, and the incentive would apply only to publicly-owned municipal utilities.

Other provisions that may benefit the geothermal industry are embraced in sections that promote the export of domestic renewable energy products and services and the feasibility of reducing greenhouse gases. In addition, there are 1) requirements for utility integrated resource planning to include evaluation of renewable energy resources, and 2) cost recovery mechanisms for demand-side management strategies that may encourage increased use of geothermal heat pumps and other direct uses of the resource.
Finally, the 10 percent business energy tax credit for qualified geothermal energy property is extended on a permanent basis. Thus, the industry is given greater flexibility in long-range planning than was provided by previous one- and two-year extensions.

\section{TECHNOLOGY ADVANCEMENTS TO SUPPORT GROWTH OF GEOTHERMAL POWER SALES IN A DYNAMIC UTILITY MARKET}

"In a decade of extraordinary change in the traditional mode of electric utility operations, doors are being opened to new participants and new technologies," Dr. John E. Mock, director of DOE'S Geothermal Division, reminded the Geothermal Program Review $X$ audience in San Francisco in March 1992. However, Dr. Mock noted, the doors will only be fully opened to geothermal energy when and where it meets the economic competition. "Thus," he said, "I see technology advancement as one of the key roles available to government to support increased geothermal power sales in a dynamic utility market. Technology improvement and innovation that translate. into reduced costs are therefore our continuing research focus."

A major market transformation currently underway in the utility sector was addressed at Program Review X -- i.e., competition in an industry commonly considered a "pure" monopoly. Among other factors, Dr. Mock noted, competition is being accelerated in the utility industry by increasing deregulation and the concomitant emergence of the independent power producers (IPPs). A major hurdle in 
the path of further deregulation was surmounted by passage of the National Energy Policy Act of 1992. This legislation exempts IPPS - both utility-affiliated and non-affiliated -- from regulation under the Public Utility Holding Company Act, thus providing a boost to an already growing industry.

To support continuing growth in this industry segment, the R\&D priorities of the DOE geothermal program "are established in accordance with what we understand to be industry's major cost-sensitive technology areas," Mock said. He added that the Department needs and solicits industry's continuing input and suggestions "in order to assure that our understanding and planning in fact satisfy industry's most pressing requirements."

Mock then briefly outlined DOE's rationale for pursuing cost reductions in three hydrothermal areas .-- exploration technology, reservoir engineering and management, and drilling -- and its general approach for achieving the objectives. He also noted the potential of geopressured resources and hot dry rock to meet future utility/industrial needs.

\section{COOPERATIVE GEYSERS RESEARCH CONTINUES; WORKING GROUPS FORMED}

Research into methods for stabilizing the rate of decline of The Geysers steam field continues as a cost-shared DOE/industry effort. In order to increase the pace of the research, instill a strong sense of its importance, and encourage optimum communication among researchers, four working groups have been formed. Each group consists of six to 12 members representing both government-funded research institutions and industry.

Their charters include:

- discussing technical problems at The Geysers

- proposing potential solutions

- prioritizing research projects

- incorporating appropriate progress of other groups into their projects.

The assignments of the four groups are as follows:

- field geological and geochemical models

injection techniques

- reservoir performance prediction

- power generation, pipelines, injection water, and corrosion control.

The federal researchers include representatives from:

- Idaho National Engineering Laboratory

- Lawrence Berkeley National Laboratory

- Stanford University

- University of Utah Research Institute 
- Oak Ridge National Laboratory

- Brookhaven National Laboratory

- U.S. Geological Survey

- Lawrence Livermore National Laboratory.

Each working group is chaired by a representative of a Geysers field developer, utility, or independent power producer with expertise in the appropriate disciplines. Dr. Phillip M. Wright of UURI has been assigned by DOE as a special program facilitator.

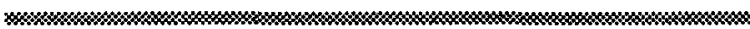

PHASE II DRILLING AT LONG VALLEY EXPLORATORY WELL COMPLETED

Phase II of the Long Valley Exploratory Well was completed in November 1991 to a depth of 7,588 feet. The site of the well is a "recently active" volcanic caldera near Mammoth Lakes, California, which has excited the geothermal community for some time. The wealth of data gathered by previous exploration of the site has raised as many questions as were answered, and it is on this basis that the probable high-temperature resource is being explored to great depths.

Total cost of the Phase II drilling was approximately $\$ 2.3$ million, shared about equally by the California Energy Commission and DOE. Phase II scientific work began in July 1992, and is supported by the DOE Office of Basic Energy Sciences, the Geothermal Division, and other funding sources.
The interests of the various participants are represented in the overall objectives of the well. They are to improve definition of the hydrothermal resource in the caldera, to determine whether crustal magma exists at depths less than 25,000 feet, to test new drilling technology, and to. further scientific understanding of the caldera's formation and evolution.

Completion of Phase III drilling to at least 14,000 feet is planned for the future. During the interim, scientific data are being gathered by participants.

(NOTE: See LEASING AND DRILLING for other DOE drilling activities.)

\section{GEOPRESSURED WELL TESTING PROGRAM BEING PHASED OUT}

Initiated in 1974 to determine the potential of geopressured brines as a major energy source, the DOE geopressured well testing program is currently being phased out. The technical goals of this research effort were to:

- confirm the existence of the resource

- establish its magnitude

- measure its characteristics

- develop a technology to recover its energy

- formulate a predictive model of the recovery process.

In support of these goals, two types of wells have been flow tested on the Gulf 
Coast of Texas and Louisiana. The first type included nine abandoned or dry oil and gas wells or "wells of opportunity" which were provided at no cost by industry, and the second consisted of four "design wells," wells drilled specifically for geopressured experimentation.

The climax of the testing program was operation of a 1-MWe hybrid power system for eight months at the Pleasant Bayou well site, the first geopressured power system in the world. While operation of the plant indicated that geopressured technology is not yet economically competitive with other energy sources due to the relatively low brine temperatures, limited methane content due to high salinity, and current economic conditions in the energy sector. the first-of-a-kind demonstration facility provided valuable data over a range of operating conditions and demonstrated that power can be produced reliably with no serious operating problems.

Accomplishments of the $\$ 190$ million, well testing and university research program included:

- successful modification of oil and gas production technology for brine production, gas separation, and brine disposal

- demonstration that the brine is generally saturated with methane

identification of a number of "fairways" in the Gulf Coast region where thick sandstone bodies have fluid temperatures higher than $149^{\circ} \mathrm{C}\left(300^{\circ} \mathrm{F}\right)$
- development with industry of a highly effective inhibitor treatment to control calcium carbonate scaling that can obstruct well flow

- production of over 27 million barrels of brine and 676 million cubic feet of gas from the Gladys McCall design well in Louisiana, and over 29 million barrels of brine and 543 million cubic feet of gas from the Pleasant Bayou well in Texas, demonstrating that long-term, high-rate brine production and disposal are feasible.

By the end of FY93, all three active wells remaining open - the Gladys McCall and Pleasant Bayou design wells and the Hulin well-of-opportunity contributed by industry - are planned to be plugged and abandoned. Interpretation of well flow data with models developed by program researchers is continuing. In addition, water quality and subsidence monitoring will continue for one year to ensure that no environmental degradation exists.

Efforts at the Idaho National Engineering Laboratory have explored the involvement of industry in direct industrial applications of the heat of geopressured brines. Feasibility studies by INEL suggest that projects such as the desalination of water, thermal enhanced oil recovery, agriculture and aquaculture, and detoxification of organic wastes could be economically viable using existing oil and gas wells. 
NEW DEVELOPMENTS IN RESERVOIR SIMULATION PROVIDE AFFORDABLE TOOLS FOR RESERVOIR MANAGEMENT

Partly due to their expense and partly because of the lack of "user friendly" codes, numerical simulators have typically not been used in reservoir engineering by the geothermal industry. Now, however, DOE-funded work at the Idaho National Engineering Laboratory has shown that a new generation of both computers and simulation codes has removed the impediments to incorporating numerical studies in the suite of tools used, and that declining costs make them available to even the smaller independent operators.

The criteria used in selecting a useful numerical simulator include such factors as ease of use, input/output options, and continued user support. The simulator must then be validated to ensure that it yields "correct" information. TETRAD is the simulator used by INEL's Geothermal Reservoir Technology Program. Based on these selection criteria, TETRAD is a threedimensional, multiphase, multicomponent, finite difference simulator, written in standard FORTRAN 77 and can run on a wide range of machines from a $386 \mathrm{PC}$ to a supercomputer.

Code validation was achieved through solution of the Stanford Geothermal Problem Set (Stanford Special Panel on Geothermal Model Intercomparison Study). Each of the geothermal problems was set up and run on TETRAD, and results obtained were compared with those presented in the Stanford report. This validation study demonstrated that
TETRAD solved all of the geothermal problem sets with similar accuracy as those simulators summarized in the report, and can, therefore, be used in future studies with confidence.

More information on TETRAD and INEL studies undertaken on its use may be obtained from:

G. Michael Shook
INEL
P.O. Box 1625
Idaho Falls, ID $83415-2107$
(208) 526-6945

GEOTHERMAL LOW-TEMPERATURE
RESERVOIR ASSESSMENT PROGRAM
-- A NEW DOE GEOTHERMAL
INITIATIVE

In Fiscal Year 1991, Congress appropriated money for the Department of Energy to begin a new program in the evaluation and use of low- and moderatetemperature geothermal resources. The program will consist of several components, including: 1) compilation of all available information on resource location and characteristics, with emphasis on resources located within five miles of population centers; 2) development and testing of techniques to discover and evaluate low- and moderate-temperature geothermal resources; 3) technical assistance to potential developers of lowand moderate-temperature geothermal resources; and 4) evaluation of the use of geothermal heat pumps in domestic and commercial applications.

The objective of the Geothermal LowTemperature Reservoir Assessment 
Program is to achieve greater utilization of the nation's widely distributed low- and moderate-temperature geothermal energy and earth-heat resources. By achieving this objective: 1) energy security will be enhanced through development of an important domestic energy resource; 2 ) the trade deficit will be reduced by displacing the need for importing so much oil; and, 31 environmental preservation will be enhanced by displacing the use of fossil fuels, which emit greenhouse and acid-rain gases and create damaging ground-level ozone.

The program will be a cooperative effort among a number of academic and state institutions working with potential direct heat developers. The three principal institutions are the Geo-Heat Center at the Oregon Institute of Technology, the Idaho Water Resources Research Institute at the University of Idaho, and the Earth Science Laboratory of the University of Utah Research Institute. Resource teams from selected states in the West will also participate. In addition, participation of eastern institutions knowledgeable in geothermal heat pumps is planned. (See related article below.)

Source: Geo-Heat Center Quarterly Bulletin $8 / 92$

\section{CONGRESSIONAL COMMITTEE SEEKS INFORMATION ON GEOTHERMAL DIRECT USE}

On July 30, 1992, five witnesses testified at a hearing on direct uses of geothermal energy called by the U.S. House Subcommittee on Environment, Committee on Science, Space, and Technology, chaired by James $H$. Scheuer of New York. The panel of witnesses consisted of: Ms. Marianne Guffanti, geologist from the U.S. Geological Survey who addressed the nature and distribution of moderate- and low-temperature resources; Dr. Robert L. San Martin, Deputy Assistant Secretary for Utilities Technology, DOE, who discussed the direct use programs of the Department of Energy; Dr. John W. Lund of the Geo-Heat Center who spoke about the development and needs of the direct use industry, including heat pumps; Mr. Joseph E. Rizzuto, Program Manager for the New York State ERDA who reported on New York's use of geothermal heat pumps; and Ms. Marika Tatsutani, Research Associate of the Natural Resources Defense Council who discussed the environmental benefits and impacts associated with the direct use of geothermal energy.

Questions at the hearing were directed toward the present and future contribution of low-to moderate-temperature resources to the national energy picture, the contribution towards improving air and water quality, the benefits of international cooperation, and the contribution of geothermal heat pumps. The latter topic was of special interest, since this has a nationwide appeal, and has the potential to displace as much as 2.7 Quads of electricity demand per year (slightly less than 700 million barrels of oil equivalent) by the year 2030 . 


\section{GHPS GET POSITIVE RATING FROM EPA}

In conjunction with the National Geothermal Heating and Cooling Teleconference, which was aired via satellite on July 21, 1992, the U.S. Environmental Protection Agency, Global Warming Division, issued a draft summary of the soon-to-be-released report on The Economic and Environmental Potential of Advanced Residential Space Conditioning Technologies. The executive summary reflects the content of the full report and is very positive toward geothermal heat pumps (GHPs).

The report explores advanced alternative space conditioning equipment and the opportunities it provides for cost effective energy savings and pollution prevention. The various technologies studied include all current and proposed forms of high efficiency electric and gas- or oil-fired systems.

Comparisons were made in six major cities covering a range of geographical and climatic regions. In all locations except Chicago and Atlanta; the GHP had the lowest overall environmental "cost" under present fuel mixes. Performance comparisons were all based on net performance and took into account the losses associated with energy production, transmission, and distribution.

According to the report, the total U.S. market demand for GHPs could increase from present sales levels of 20,000 units annually to over 450,000 by the year 2000. The resultant impact on generating capacity could save over 15.6 billion $\mathrm{kWh}$ per year and displace some 6,183 MWe of generating capacity by the year 2000 . By the year 2005, these savings could increase to 38.6 billion $\mathrm{kWh}$ and 15,513 MWe of winter capacity. Accordingly, reductions in the emissions of $\mathrm{CO}_{2}$ could reach 10.9 million tons per year by the year 2000, and 27 million by 2005 based on a composite emissions average for all current generating technologies.

The EPA suggests the formation of a consortium of utilities, power authorities, public agencies, and conservation groups to accelerate the development, commercialization, and distribution of energy efficient technology. EPA has also indicated a willingness to fund an initiative to implement an incentive program. (See related articles in DEVELOPMENT STATUS, LEASING AND DRILLING and TECHNOLOGY TRANSFER.)

Source: Geothermal Resources Council Bulletin 8/92

\section{HOUSE OF REPRESENTATIVES PANEL INVESTIGATES HOT DRY ROCK}

On the House Interior and Insular Affairs Subcommittee on Energy and the Environment held an oversight hearing January 23, 1992, to explore the promise of hot dry rock technology. Chaired by Representative Peter H. Kostmayer of Pennsylvania, the subcommittee heard testimony from witnesses representing the U.S. Department of Energy, Los Alamos National Laboratory, National Geothermal Association, MIT Energy Laboratory, Stanford University, Geothermal Power Company, and GeoScience Ltd. 
In his opening remarks, Chairman Kostmayer stated that the purpose of the hearing was to investigate "... efforts to develop alternative energy sources, in particular hot dry rock geothermal energy." He compared current U.S. investment in HDR with European and Japanese budgets and voiced concern about America losing leadership in hot dry rock technology. Topics covered at the hearing included the federal budget for HDR R\&D and future plans for the federal hot dry rock $R \& D$ program, efforts to commercialize HDR technology, the HDR program at Los Alamos National Laboratory, technical obstacles to HDR economic viability, and international R\&D efforts to develop HDR.

\section{FLOW TESTING INITIATED AT FENTON HILL HOT DRY ROCK RESERVOIR}

Extended flow testing of the hydraulically-fractured hot dry rock reservoir at Fenton Hill, New Mexico, was initiated in April 1992, after completion of the surface plant facility. The primary objective of the test is to demonstrate that energy extraction from the hot dry rock reservoir can be sustained. The test will also provide important information about water needs, operational and maintenance parameters, parasitic power consumption, and thermal lifetime - data that are required before industry can decide to build a commercial hot dry rock facility.

In preparation for the extended flow testing, three 3-day tests and one 10-day test were conducted between December 1991 and March 1992. These preliminary tests served as commissioning trials for the surface plant and defined the parameters for operating the reservoir under steadystate conditions - the operating mode recommended by the Hot Dry Rock Program Development Council, an industry advisory panel. Under steady-state conditions, the system operates at the highest injection pressure that can be sustained without reservoir expansion, as evidenced by the lack of significant seismic activity at the reservoir periphery, and within the limits of the available water supply.

The extended flow test began on April 8, 1992, and ran almost continuously for four months before encountering mechanical problems with the injection pumps. During this initial operating period, fluid was injected at about 116 gallons per minute at approximately 3,900 psi. Fluid was produced at about 100 gallons per minute at a temperature of $184^{\circ} \mathrm{C}\left(365^{\circ} \mathrm{F}\right)$. This is equivalent to roughly $4.4 \mathrm{MW}$ of thermal power, or $0.6 \mathrm{MWe}$ at 15 percent conversion efficiency. The reservoir was maintained in a pressurized state while waiting for delivery of a new pump. Once the new pump was installed in December 1982, the extended flow test was resumed at the originally planned steady-state conditions.

Several significant findings have resulted since the flow testing began. Early operating experience together with the results of a tracer test conducted in March indicate that the reservoir, which had been dormant or pressurized but not flowed for a number of years, has maintained its physical stability over time. Tracer tests conducted during May and July (see graph) showed that the tracer injected in July was detected in the production fluid later and returned more slowly than the tracer injected during May. 
Researchers believe that the circulating fluid in July was following a more diffuse path through the reservoir and contacted more rock than in May. Hence, the thermal capacity of the system has increased with time. Additionally, a shutdown of the injection system for a few hours is possible without affecting the operation of the production portion of the system -- an important finding from a commercial standpoint.

\section{Comparison of Two Tracer Experiments p-Toluenesulfonic Acid Concentrations as a Function of Produced Volume}

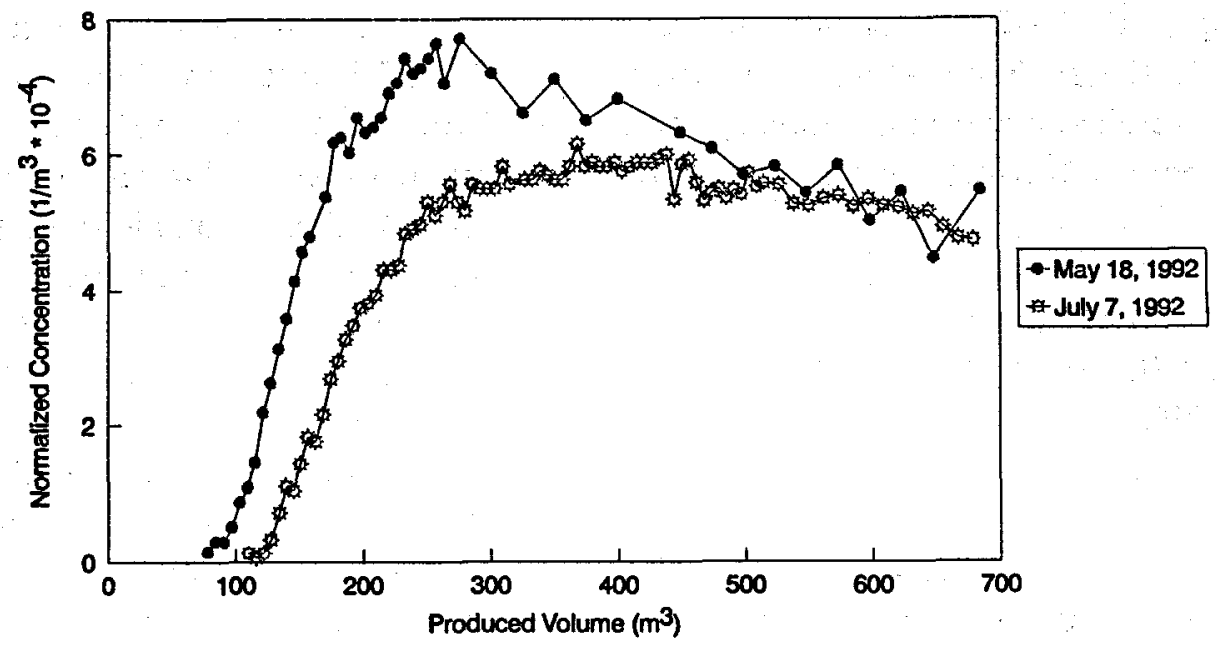

Tracer Recovery Curves at Fenton Hill Reservoir

Results show that the initial recovery of the tracer occurred at a markedly greater production volume during the July test and that the total amount of the tracer recovered las indicated by the area under the curve) was less. The two curves appear to converge and follow similar paths beyond a production volume of 500 cubic meters. A comparison of the curves up to that point indicates that about 6 percent less of the total flow reached the production wellbore via direct pathways in July.

\section{TWO GEOTHERMAL RESEARCHERS} RECEIVE AWARDS

On June 15, 1992, Dr. Eugene T. Premuzic of Brookhaven National Laboratory was awarded a Certificate of Environmental Achievement by Renew
America for his research program, Advanced Biochemical Processes for Geothermal Brines. The objective of this research is to develop economic and environmentally acceptable methods for removing hazardous metals from residual geothermal sludges and to significantly reduce disposal costs associated with hazardous waste disposal. The advanced 
biochemical process being developed involves using patented microorganisms to remove the metals, such as mercury, arsenic, chromium, and copper, and produce metal concentrates, inert construction materials, or a liquid injectate suitable for disposal. The process will be listed in the 1992 Environmental Success Index that is made available to policymakers, citizens groups, private and public organizations, the media, and individuals interested in finding solutions to environmental problems. As part of the Index, Dr. Premuzic's program will also be promoted as a model for others.

The other award was presented to Robert Fournier of the U.S. Geological
Survey at the December 1991 winter meeting of the American Geophysical Union. He received the N.L. Bowen Award of the Volcanology, Geochemistry, and Petrology Section of the AGU for outstanding contributions in the area of chemistry of hydrothermal fluids. Dr. Fournier is well known throughout the geothermal industry as the "father" of silica geothermometers that can be used "to predict the temperature and chemical characteristics of geothermal reservoirs at depths of several kilometers."

Source: Geothermal Resources Council Bulletin 6-7/92 


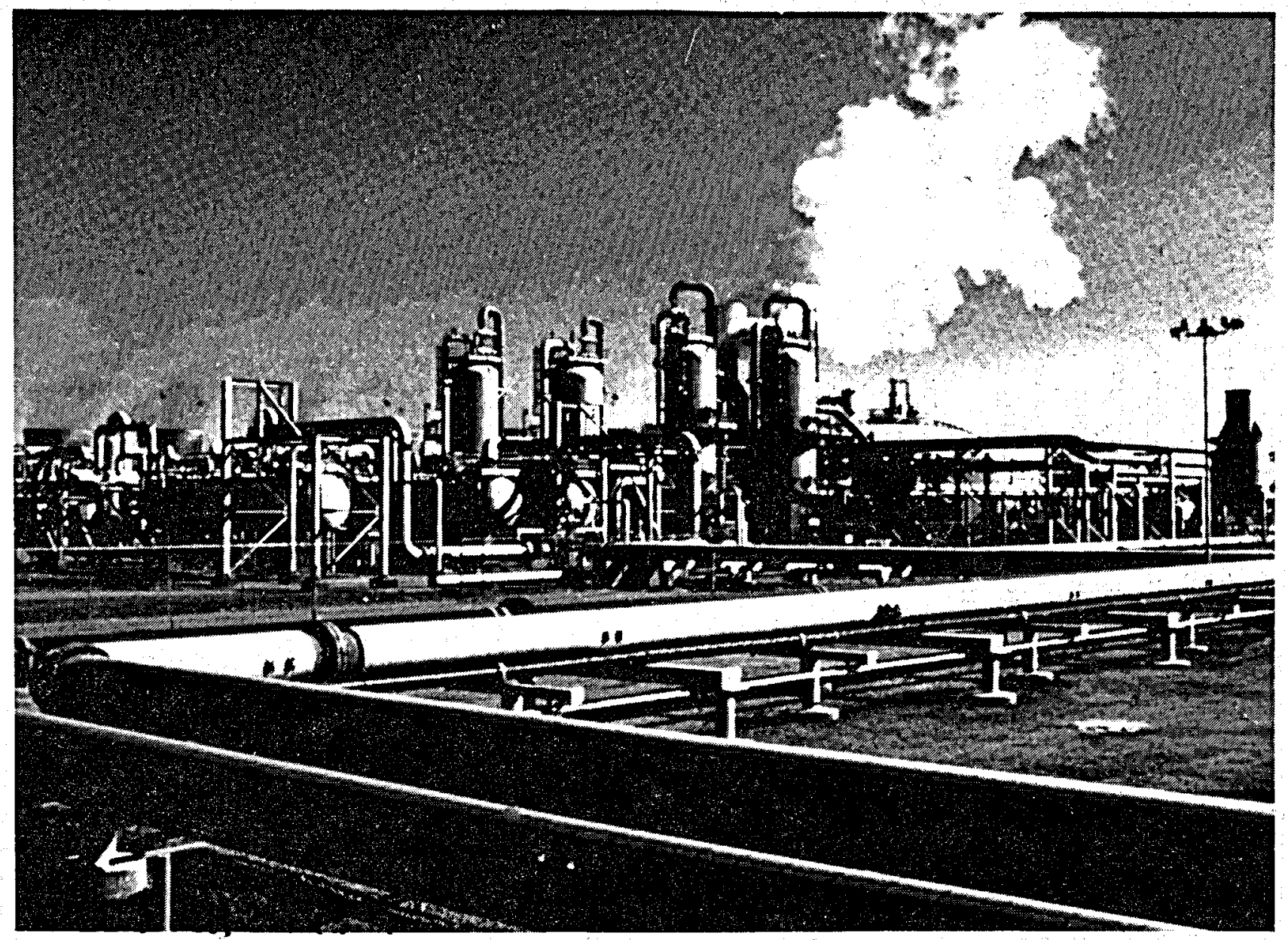

Unocal Salton Sea Plant No. 3 in California's Imperial Valley which, at $47.5 \mathrm{MWe}$, is the largest Unocal property being acquired by Magma Power Co. (See adjacent article.) 


\section{MAGMA TO ACQUIRE SEVERAL OF UNOCAL'S GEOTHERMAL ASSETS FOR SALE}

Magma Power Co. said it signed a definitive agreement to buy several of Unocal Corporation's profitable geothermal assets for $\$ 225$ million. The assets include all of Unocal's geothermal operations in Imperial Valley, California, including three power plants; Unocal's Long Valley geothermal leases in Mammoth, California, and its leasehold acreage in Nevada.

Paul M. Pankratz, Magma's chairman, president, and chief executive, said the acquisition would boost Magma's revenue by about $\$ 74$ million, or 78 percent next year. Net income could increase by as much as 40 percent, he said, but he declined to estimate per-share earnings. In 1991, Magma earned $\$ 34$ million, or $\$ 1.44$ a share, on sales of $\$ 95$ million.

Analysts viewed the transaction as a good deal for both parties. For Unocal, a diversified oil company based in Los Angeles, the sale complements a plan to cut operations, reduce debt, and increase cash flow. The acquisition gives Magma new clout in the power industry by raising its electric-generating capacity by 50 percent.

Wall Street reacted favorably to the news. In national over-the-counter trading, Magma shares closed at $\$ 27.50$, up $\$ 3.00$.

Of the $\$ 225$ million purchase price, $\$ 100$ million will be in retained cash and the remainder in corporate debt, according to Mr. Pankratz. The Unocal assets will increase Magma's power-generating capacity to 240 megawatts from 160 megawatts. Magma, a geothermal power plant operator, already has facilities in the inland desert Imperial Valley area.

"This acquisition increases our resources and significantly improves our competitive position on new contracts," Mr. Pankratz said.

A spokesman for Unocal said the company anticipates a slight gain from the deal that would be reflected next year after the sale closes. The transaction is expected to close by March 31, but all revenue and earnings from the Unocal assets will accrue to Magma as of Jan. 1 . In addition to the initial sales price, Unocal will receive up to $\$ 15$ million in contingent payments from Magma based on the addition of new power-generating capacity and a 1 percent royalty on the revenue from such additions."

Unocal said it plans to use some of the proceeds toward overseas resource development, particularly in Indonesia.

"You're seeing a desire to meet goals and expectations that (Unocal) laid down earlier in the year," said Thomas $C$. Lewis, group vice president of energy company analysis at Duff \& Phelps Inc. "When a company comes out with an aggressive plan, I think the worst thing they could do is disappoint the marketplace."

Kit Konolige, an analyst who follows Magma for First Boston, said he revised his 1993 earnings forecast to $\$ 2.30$ a share from a previous $\$ 1.75$ estimate. $B y$ increasing their size and financial flexibility, Magma has increased the ability to provide any capacity they might bid for," he said. 
Source: Wall Street Journal, December 17. 1992

\section{CAL ENERGY DEVELOPMENT CONTINUES; LAND POSITION IN PLACE FOR FUTURE ACTIVITY}

The California Energy Co. is the managing partner at the $240 \mathrm{MWe}$ geothermal power installation at Coso, owning approximately 50 percent interest; the Company retains sole ownership of a property at Desert Peak acquired in 1991; and has a 70 percent interest and management responsibility in the geothermal steam field at Roosevelt Hot Springs, also acquired in 1991. An accelerated drilling and exploration program was launched at Coso in 1991, designed to increase reserve steam capacity, prepare for additional production, and explore other regions of the reservoir. Based on favorable results achieved last year, the accelerated program has continued into 1992.

Still another initiative during 1991 was organization of a team experienced in project development to pursue other opportunities aggressively. As an example of the team's early success, the company points to its selection by the Bonneville Power Administration to develop a 30 MWe geothermal power plant in Oregon, with an option for an additional $100 \mathrm{MWe}$. Under the project, which California Energy hopes to bring online in 1995, power would be sold to both BPA and the Eugene Water and Electric Board, for resale to other regional utilities.

The company's land position encompasses over 500,000 acres of highpotential geothermal properties in five western states. This includes lease rights to approximately 24,000 prime acres at Desert Peak.

The company's plants continue to demonstrate the "head-and-shoulders" reliability of geothermal energy in power generation with a 99 percent availability factor in 1991 at both Coso and Desert Peak. The average availability rate for fossil-fired plants is about 78 percent and 65 percent for nuclear.

Source: California Energy Co. 1991 Annual Report

\section{CALPINE CORPORATION CHOSEN TO NEGOTIATE FOR LADWP COSO PROJECT}

In January 1992, Calpine Corporation announced its selection by the Los Angeles Department of Water and Power (LADWP) to enter into negotiations on contracts to develop a 150 MWe geothermal facility at LADWP's Coso leases in southern California. Calpine was selected from the three short-listed respondents to a Request For Proposals for development of the Coso geothermal leases. The selection criteria included economic, financial, and technical considerations of each proposal in addition to experience in operations and development resources.

Calpine proposes to develop, operate, and maintain the $150 \mathrm{MWe}$ geothermal facility, with the first two $30 \mathrm{MWe}$ units to be operational in 1996. The remaining 90 MWe would be added in the year 2000. When fully developed, the installation will account for about 2 percent of LADWP's 
total electrical output of about 7,500 MWe.

LADWP has leased more than 6,800 acres of land in the Coso area from BLM since 1981. Construction of the plant is expected to employ more than 500 people, and operation of the plant will require about 100 people.

Source: Geothermal Resources Council Bulletin 2/92

\section{ORMAT ENERGY SYSTEMS CONTINUES DEVELOPMENT}

Having expanded its Soda Lake geothermal plant by $11.7 \mathrm{MWe}$ in 1991 . Ormat Energy Systems (OESI), Portland, OR (formerly located in Sparks, NV) has continued development activities through 1992. Besides participation in the Puna Geothermal Venture (see Puna article in this section), OESI has been conducting exploration and drilling activities at its Rye Patch prospect in Nevada. The company announced in January 1992 the completion of a geothermal production well, No. 44 . 28 , at the field, located near Lovelock, Nevada. Drilling began on October 8 , 1991, and was completed on November 10,1991 , at a depth of approximately 3,500 feet. Downhole temperatures have been measured at above $204^{\circ} \mathrm{C}\left(400^{\circ} \mathrm{F}\right)$ with a stabilized flow rate of 500,000 pounds per hour.

Completion of a 21-day flow test on January 7, 1992, confirmed the existence of a viable reservoir. The company plans to drill an additional production well to confirm the extent of the reservoir. The project will require four production wells (including one standby), and three injection wells (including one standby) to process over 1.5 million pounds of geothermal fluid per hour.

The plant, named the "Rye Patch $A$ " (formerly named the "Carson Basin $A^{\text {") }}$, will be the 11th geothermal facility constructed by the company. It is expected to produce 14 MWe of electricity for sale to Sierra Pacific Power Co. under the terms of a 30-year power purchase agreement previously executed by the two companies. The commencement of commercial operations is expected in June 1993. If further testing and production experience at Rye Patch indicate additional resources, OESI may construct a second plant at the field to satisfy another 14 MWe contract with Sierra Pacific.

OESI has also been pursuing development of its prospect on Unalaska Island, off the coast of Alaska. Negotiations with the Alaska Power Authority are continuing las of September 1992). Construction of a road to the site is expected to begin in the summer of 1993, and drilling is scheduled for the summer of 1994.

Strengthening its development team, OESI recently acquired a 20 percent interest in LFC Power Systems Corp. (PSC), a company which provides construction management and operations and maintenance services for power plant projects. OESI will acquire the remaining 80 percent in January 1993, with the total purchase price being approximately $\$ 860,000$. PSC, headquartered in Portland, 
Oregon, is a subsidiary of LFC Energy Corp., which is an affiliate of LFC Financial Corp., a holder of 40 percent of OESI's common shares. PSC has about 180 employees and operates nine power plants in four states, including the Ormesa 1 geothermal facilities in the Imperial Valley, California. James W. Porter Jr., Chief Executive Officer of OESI, said "this acquisition will give us access to PSC's expertise in the construction, operation, and maintenance of power plants. OESI has a number of projects in development or under consideration, and this acquisition will provide us additional resources needed to take advantage of our significant growth opportunities."

Sources: Geothermal Resources Council Bulletins 1/92, 12/91, 2/91

\section{OXBOW POWER SERVICES, INC. TO OPERATE NEW BRADY POWER PLANT}

Oxbow Power Services, Inc. (Reno, Nevada) announced on January 20, 1992. that it had been awarded the operations and maintenance contract for the Brady Power Plant Project in Brady Hot Springs, Nevada, currently under construction. The plant is owned by a partnership composed of FSI Energy (an affiliate of Flower Power and Light) and Nevada Geothermal Power Partners. The 20.6 MWe production from the Brady Project is being sold to Sierra Pacific Power Company. Oxbow Power Services also operates the plant at Beowawe in which Oxbow Power of Beowawe is a partner. Another Oxbow company, Oxbow Geothermal Corporation, owns and operates a $65 \mathrm{MWe}$ plant in Dixie Valley. Oxbow Power Corporation, headquartered in West Palm Beach, Florida, is the parent corporation.

Source: Geothermal Resources Council Bulletin $3 / 92$

\section{HAWAII PUNA PROJECT BACK ON TRACK}

The 25 MWe Puna Geothermal Venture (PGV) plant under construction in Hawaii is back on track following months of regulatory and litigative challenges triggered by the loss of control of production well KS-8 during drilling in June of 1991. PGV is a joint venture of OESI Power Corporation and Constellation Development.

PGV's drilling permits were suspended pending investigations by the state and county. The investigations included reviews of KS-8 well drilling equipment and procedures, emergency response procedures, and gaseous emissions and noise mitigation, including monitoring and enforcement. Based on recommendations from the investigating teams, the suspension was extended in July to include all activities at the site exclusive of efforts to regain full control of $\mathrm{KS}-8$.

In October 1991, after PGV regained control of KS-8 by drilling a water well nearby and using the cold water to quench KS-8, the county lifted its suspension of all non-drilling construction activities. Construction of the plant was completed and service tests of the plant were allowed in early 1992. Rather than postponing the tests until geothermal steam became available from its wells, PGV brought in a mobile boiler to produce the steam. 
Permission to drill remained in abeyance while a joint state and county task force completed a geothermal management plan which addressed drilling, emergency response procedures, and other related issues.

Constellation Development assumed management of the project early in 1992. and late in February the state announced that PGV had met the health, safety, and drilling criteria imposed by the task force, and the drilling permits were reinstated. However, opponents of the project quickly halted further drilling with court action resulting in a stay order requiring suspension of all drilling activities pending the formulation of new regulations governing $\mathrm{H}_{2} \mathrm{~S}$ emissions. $\mathrm{New} \mathrm{H}_{2} \mathrm{~S}$ emissions regulations became effective at the end of June 1992, allowing PGV to apply for a new $\mathrm{H}_{2} \mathrm{~S}$ emissions permit. Upon issuance of the new permit, site work resumed in July. PGV conducted a short-term flow test of production well KS8 in August. Late in October, the plant began generating about 5 MWe using production from well KS-8. However, late in the year the decision was made to plug KS-8 and drill a new production well, scheduled for completion this spring. Well KS-4, an injection well, was completed and successfully tested in December.

Source: Geothermal Resources Council Bulletin 2-6/92 and 11/91, Geothermal Hot Line 12/91, and personal communication with OESI Power Corporation and the State of Hawaii
MAGMA POWER PLANS NEW 16 MW PLANT AT FISH LAKE, NEVADA

Magma Power Co., San Diego, California, plans to develop a $16 \mathrm{MWe}$ geothermal plant in the Fish Lake area in Esmeralda County, Nevada. Magma purchased a Standard Offer No. 4 Contract for the site from Geothermal Resource Partners - 1983 (GEO-83). Magma and GEO-83 have formed an equal partnership called Magma/GEO-83 to develop the Fish Lake plant. Magma contributed 28,800 acres and GEO-83 19,200 acres to the partnership. The SO-4 contract has a fixed capacity payment for the full 30-year term at $\$ 187 / \mathrm{kW}$-year, or less than 3 cents/kWh. Energy payments are fixed at 10.2 cents/kWh for 10 years starting in 1996 and then escalate at an average annual rate of 3.9 percent. For the next five years, the energy payment is set at Edison's then-published avoided cost. Magma must still obtain siting and environmental permits before commencing construction, but they are confident the project will meet its January 1997 online deadline.

Source: Geothermal Resources Council Bulletin 5/92 

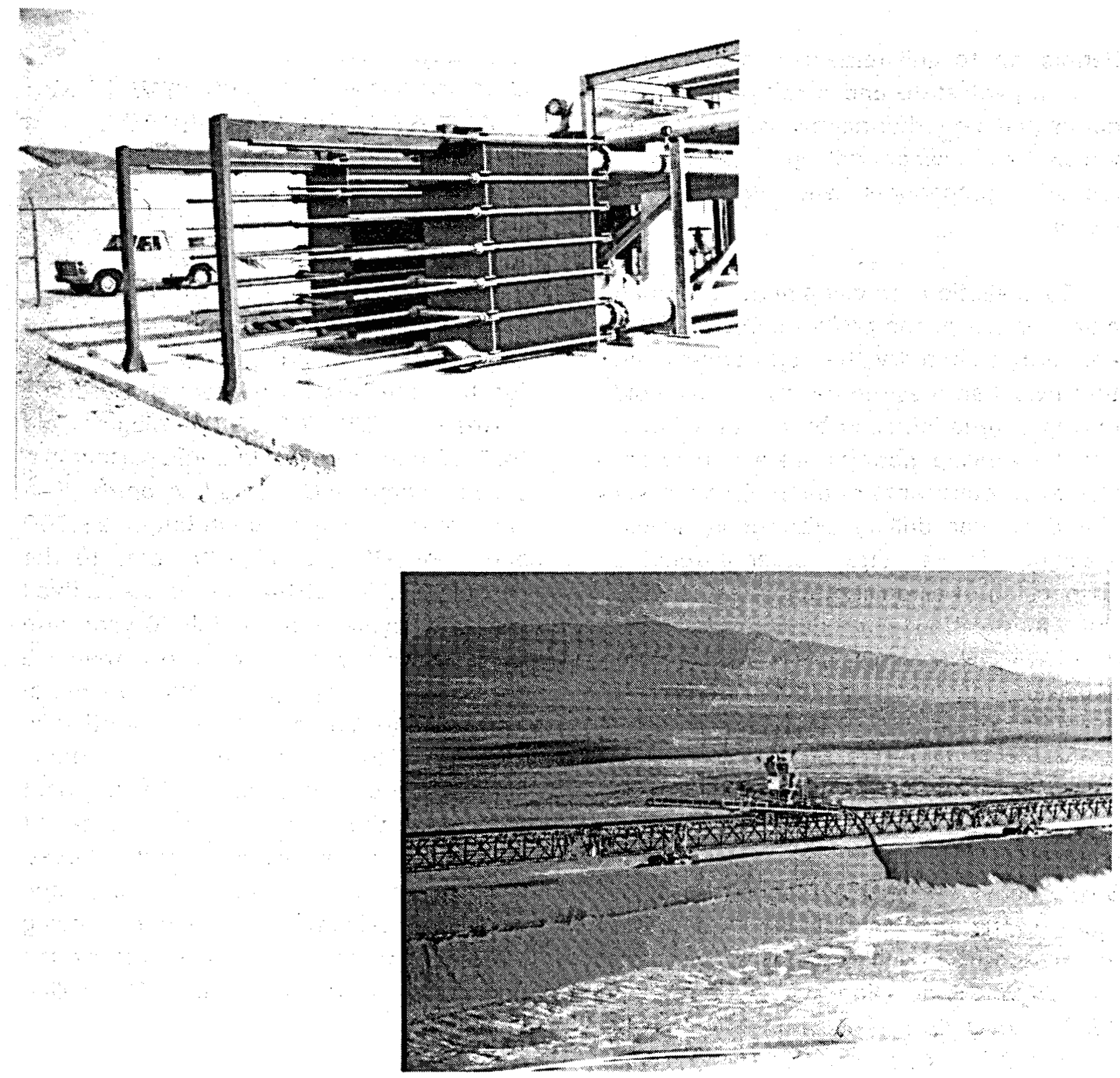

\section{Geothermal Use in Gold Mining}

As a result of research conducted by the Division of Earth Sciences, University of Nevada, Las Vegas, two Nevada gold mines use geothermal fluids in their heap leaching operations. The addition of heat to the process provides two major advantages -- year-round production, independent of prevailing weather conditions, and increased metal recovery. The photo at the top of the page shows the tranter super changers of the Round Mountain Gold Mine in which geothermal fluids at $82^{\circ} \mathrm{C}\left(180^{\circ} \mathrm{F}\right)$ heat cyanide process water from $5.6^{\circ} \mathrm{C}\left(42^{\circ} \mathrm{F}\right)$ to $23.3^{\circ} \mathrm{C}\left(74^{\circ} \mathrm{F}\right)$ in winter; lower photo depicts a radial arm stacker loading ore at the Florida Canyon Mine of the Pegasus Gold Corporation. 
GEOTHERMAL POWER CONTRACTS FEATURED IN GRC BULLETIN

The October 1991 issue of the Geothermal Resources Council Bulletin featured three articles relating to geothermal power contracts. In the first article, William P. Short III, vice president of Kidder, Peabody \& Co., Inc., discussed the trends in the U.S. geothermal industry, noting that the industry began in 1960 as a seller of geothermal steam to electric utilities at The Geysers, but has now evolved into an industry that generates and sells electricity directly to utilities. He detailed the four major types of steam/brine contracts and four principal types of power sales contracts.

Short also pointed out that although there were significant changes in the geothermal industry between 1984 and 1990, these developments pale against the changes that occurred in the value of geothermal properties .. from approximately $\$ 2$ billion to approximately $\$ 3.75$ billion for a compound annual growth rate of 11 percent. A significant decline in value occurred at The Geysers, but was offset by phenomenal growth in value at other operating fields.

In a second article, "Negotiating the Geothermal Steam Sales Contract," Grace A. Carter and Robert S. Span, of Paul, Hastings, Janofsky \& Walker, focus on the essential elements of a geothermal contract and provide a checklist for negotiating and drafting a contract that will meet both parties' needs over time. Today's negotiators, they point out, have major advantages over the geothermal pioneers who wrote the first geothermal contracts at The Geysers. These advantages include: the benefit of reviewing a number of prior contracts, not only for The Geysers, but for other fields; superior knowledge of the economic and technical aspects of operating a geothermal field over a period of 15, 20, or more years; and broader expertise to draw upon, ranging from investment bankers finding innovative ways of financing the project, to engineers/consultants who can anticipate the effects of declining steam production, changed economic conditions, and an evolving regulatory climate.

In a third article, a schedule of western utility requests for proposals was provided by John Geyer of Citizens Power and Light Co. of Portland, Oregon. The schedule was prepared to demonstrate that there is a real need for power in the western states. While all of these negotiations are now closed, a list of key persons in some of the states and agencies involved with their phone numbers will remain useful to interested parties in the future.

\section{UNCERTAIN NATURAL GAS PRICES CLOUD 11TH YEAR OPTIONS FOR INTERIM SO4 CONTRACTS}

Writing in the July 1992 GRC Bulletin, Thomas C. Hinrichs, of Magma Power Co., pointed out that after a 10 -year period of known fixed energy payments under Interim Standard Offer No. 4 contracts with California utilities, the price goes to the "avoided cost" of the buying utility. The utilities' avoided costs, Hinrichs noted, "track directly the delivered cost of natural gas, and most forecasts are showing that the price of gas will be significantly lower 
than the last year of the fixed period of energy payments."

The first geothermal contract to reach the end of the initial 10-year period will be in early 1994, a few in 1995 and 1996. with the majority reaching this stage in the 1997-2000 period. During this timeframe, Hinricks said, the direction of natural gas prices is highly uncertain.

The 1504 contracts can be modified when unanticipated changes occur, and Southern California Edison, in its concern for the viability of the contracted supply after 10 years, has suggested that the power producers might be willing to drop the price in the initial period in return for some certainty on price following the initial period. Hinrichs said, however, that "as long as there is an impression that gas prices may take a major step increase between now and the end of the 10-year period, it will be very difficult for lpower producers] to reduce their anticipated revenue in the short-term to gain greater certainty in the long-term." He made these recommendations to geothermal operators with ISO4 contracts:

- Become knowledgeable of the natural gas industry.

- Become familiar with how the avoided cost of your utility customer is determined and participate in the procedures of the cognizant regulating agency.

- Be prepared within the next one or two years to make a conscious decision on a course of action, and, finally, since resource developers have a great deal in common with farmers, "lay up in the good times for the droughts are always going to come!"

\section{CALIFORNIA ENERGY CO. AND MAGMA POWER INCLUDED IN 100 FASTEST-GROWING AMERICAN COMPANIES}

California Energy Company and Magma Power were included in Fortune magazine's list of America's 100 fastest-growing companies. The article praised the companies for creating jobs and enriching investors despite the recent lackluster economy. California Energy Company's (CECo) president, Richard Jaros, was featured on the magazine's cover. The article reported that CECo was in poor financial condition two years ago despite sharply rising sales. Upon purchasing a major stake in CECo, Peter Kiewit \& Sons, a large construction firm in Omaha, Nebraska, installed Jaros as president. Jaros cut the company's overhead in half and moved the company's headquarters from San Francisco to Omaha. The overhaul resulted in a 122 percent increase in earnings in 1991, and an increase in net profit margins from 13 percent to 20 percent. CECo was ranked 11 th (ranked by annual growth rate in sales over the last 3-5 years) with an annual sales growth rate of 138 percent. Magma Power was ranked 95 th with an annual sales growth rate of 51 percent.

Source: Fortune Magazine 10/05/92 
GEOTHERMAL'S FUTURE TIED TO REDUCED COSTS ACCORDING TO SCE SPOKESMAN; CALLS FOR FEDERAL ROLE

"The geothermal industry is here to stay," Vikram S. Budhraja of Southern California Edison told attendees of DOE's Program Review $X$ in March, adding that "it plays an important part in Edison's and the nation's energy mix." However, he said that while "we like the diversity geothermal provides, if it's more costly than other options, building more capacity would be imprudent."

Noting that in 1991, geothermalgenerated electricity cost Edison customers $10 \mathrm{c} / \mathrm{kWh}$ compared with a $3 \mathrm{c} / \mathrm{kWh}$ average cost of natural gas, he said, "as we look ahead, we need to design public policy approaches that aligh the interests of the resource developers, utilities, and customers to assure cost-effective development and benelefits for all." Such approaches, he said, might include subsidies in the form of tax incentives for geothermal, rembval of tax incehtives for fossil fuels, and/or taxation of air emissions. However, Budhraja salld that "the subsidy issue presents a major public policy question on gebthermal and other renewables: should we spend money to commercialize them if they are not costeffective, or should we spend money to improve their cost-effectivehess?"

He answered this question by stating that "Edison's renewable resource strátegy is aimed at making renewables costcompetitive so they can be economically integrated into our future energy mix. To drive the cost of geothermal down, Edison will continue to work with the geothermal industry, our customers, and the government to:

- "Develop promising new technologies and improve existing technologies, and

- Support a national energy strategy that provides broad-based funding for renewables... and enable sustainable and cost-effective introduction of renewable technologies without hurting competitive relationships."

He emphasized that it is "vitally important" for federal funds to be directed to this effort, pointing especially to the need for higher risk R\&D through collaborative research programs. "The next crucial step," he said, "for these types of technologies to become more competitive is to transfer them from the laboratories and demonstration projects to the marketplace."

"Joint venture funding can play a key role" in expensive demonstration projects, he added, noting that "investment partners are essential to help reduce [their] economic risk." However, Budhraja added that the renewable industry has suffered from a lack of access to sufficient capital, He suggested that "DOE can play an important role by helping reduce the economic risk assumed by private investors and by leveraging private financial resources." In closing he concluded:

"The future of alternative/renewables, in general, and the geothermal industry in particular, looks bright. We have the commitment and technological know-how to advance geothermal and other 
alternative renewable resources. All we need are the proper partnerships and policies - and I'm confident in our abilities to develop these partnerships and policies."

Edison owned and operated the first "hot water" geothermal plant in the U.S., and also was the first to demonstrate dual flash technology. The utility currently has 633 MWe of geothermal capacity, or 3.2 percent of its system mix.

\section{TAKING THE HIGH GROUND: GEOTHERMAL'S PLACE IN THE REVOLVING ENERGY MARKET}

"To meet the opportunities which are opening to us in the marketplace," Richard Jaros, new president of California Energy told Program Review X, "we, as an industry, must take the high ground - the high ground in terms of our environmental performance, in terms of the reliability of our supply, in terms of our increasing cost competitiveness, and in terms of a responsible approach to how we manage our business and conduct our commercial relations."

"We must aggressively use that position on the high ground" he added, "to push geothermal to the top of our nation's agenda. As an emerging industry, we have accomplished much, but have much progress left to make."

After exploring mechanisms being addressed by California and other state regulators that would tend to advance geothermal's market share - e.g., inclusion of externalities in power costs, set-asides for renewables, higher efficiency standards for cogeneration -- Jaros concluded that "clearly, we can see more renewables on the planning horizon, with geothermal looming large in the West." He stated that to "turn plans into plants, we must aggressively state our case and improve our case. We must demonstrate, through performance, our ability to responsibly explore, develop, build, and operate our facilities. And perhaps more importantly, we must help create a level playing field for geothermal to compete in the marketplace."

He cited two market "inefficiencies" that must be overcome to level the field -1) customers are focused on short-term costs and benefits rather than on the longterm fuel cost benefits that compensate for somewhat higher front-end capital costs, and 2) the ineffectiveness of today's energy market in pricing the societal costs of fossil fuels. He called for more federal help in reducing drilling and exploration costs -- specifically, expansion of the DOE slimhole drilling program .- and a production tax credit in addition to the investment credit. "Production credits would reward success, and not failure, by providing a benefit only to projects that produce electricity."

In conclusion, he called on the "entire community of interest" - Department of Energy officials and staff, other federal and state agencies, the scientific and environmental communities, developers, utilities, and others -- to provide more information to the public on the value of geothermal energy. "The market is there," he said, "and the cleaner, more efficient resources are there, too - up on the high ground." 


\section{GEOTHERMAL HEAT PUMPS BENEFIT THE CONSUMER, UTILITY, AND NATION}

Geothermal heat pumps (GHPs) offer utilities a highly favorable, cost-effective demand-side management (DSM) tool, according to Lew Pratsch of DOE's Geothermal Division. Although the GHP capital cost is comparable to that of the new high-efficiency air-source heat pumps, a GHP uses less energy, offering homeowners and building operators lower life cycle costs. The utility benefits by achieving better load balance, thereby reducing the need for more capacity; the consumer benefits by reduced utility bills and fewer brownouts; and the nation benefits by lower energy consumption, lower power costs for industry, and fewer adverse environmental impacts.

However, before these factors can provide a major stimulus for growth in GHP use, innovative regulatory mechanisms are needed to enable utilities to earn a fair rate of return on DSM as an element of Integrated Resource Planning. The nation needs to shift from the traditional regulatory process whereby utilities currently make money on kilowatts sold while losing money on kilowatts saved through DSM, Pratsch stated in the GeoHeat Center Quarterly Bulletin of April 1992.

In fact, Pratsch continued, "due to the beneficial externalities of DSM and renewable energy - reduced pollution, energy savings, national security, and diversity - the utilities should probably be permitted to earn a higher profit on DSM." In Connecticut, he noted, the Department of Public Utility Control has authorized a higher lsturn for utility demand-side investment, and utilities have also been asked to evaluate externalities qualitatively in their resources plans. In Rhode Island, New York, Massachusetts, and California, to name a few states, the regulators are providing profit incentives to utilities for investing in energy conservation.

Heating, cooling, and water heating -the electricity market served by GHPs -represents the single largest portion of electricity sales. That portion also is the major source of peaking problems experienced by utilities. The annual energy consumption of GHPs is 30 percent less than air-source heat pumps and 50 percent less than electric resistance heating systems. From DOE's perspective, Pratsch said, "This is a big advantage over traditional electric heating systems and thermal storage systems, which shift power demands from peaks to valleys, but consume more power."

As of 1992, an estimated 150,000 GHPs were in service. The industry is growing about 25 percent annually, and all major GHP companies continue to expand their manufacturing capacity.

Pratsch credits the stimulus in interest in GHPs to the leadership of PSI Energy, a major Indiana utility, and the nation's rural co-ops in identifying and promoting their benefit. (See related articles in FEDERAL BEAT, LEASING AND DRILLING, and TECHNOLOGY TRANSFER.) 
MINING GEOTHERMAL RESERVOIRS

Recognizing the potential value of metals such as zinc and silver dissolved in the geothermal fluids used by its four Salton Sea power plants, Magma Power Co. is now researching the economics and commercial viability of recovering these and other valuable minerals in a joint venture with Cyprus Minerals Co. of Denver. Testing is currently in the miniplant phase with installations at two of the Salton Sea plants. Early results are encouraging, and, according to the Magma 1991 Annual Report, the next phase will be a 30-gallon/minute pilot plant; full-size production could begin as early as late 1993.

The extraction process differs considerably from conventional mining in that it avoids the high capital costs and environmental impacts of mining ore crushing, separation, and smelting. In this process, the geothermal fluids are put into contact with a liquid ion exchange (LIX) which bonds with zinc. The zinc is then separated in a stripping unit and placed in another medium which, in turn, goes to an electrolytic recovery exchange for zinc recovery. As part of this solution mining process, silver is also displaced, precipitated, and recovered.

Magma estimates that full production at its four existing Salton Sea plants could recover up to 50 million pounds of zinc and 600,000 ounces of silver annually, generating considerable additional revenue. This revenue would effectively lower plant operating costs and, therefore, the cost of electricity they produce.

Source: Magma Power Co. 1991 Annual Report to Shareholders

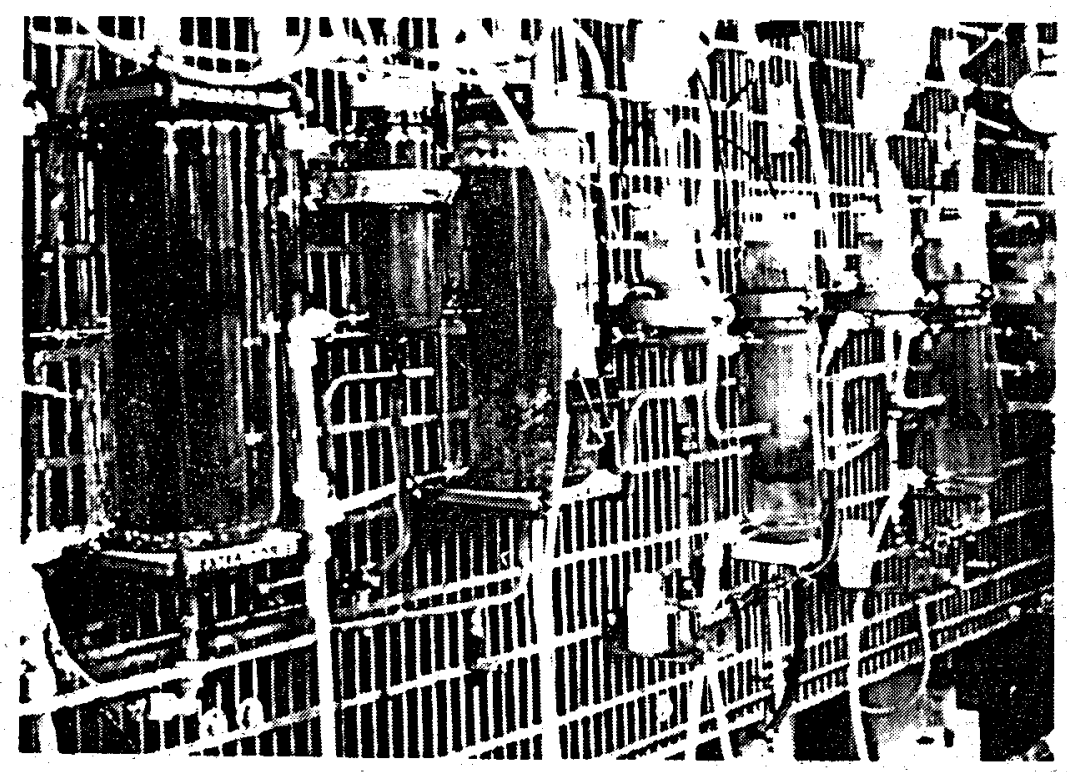

Magma Power Co. mini-plant demonstration of metal recovery from geothermal fluids at the Salton Sea (Photo Courtesy of Magma Power Co.) 


\section{LOADS AND RESOURCES STUDY SEE 800 MWe DEFICIT IN PACIFIC NORTHWEST BY 2000}

The January 1992 Bonneville Power Administration Journal announced that the federal power system in the Northwest currently has a deficit of 400 MWe, almost twice as much as last year, and the shortfall will rise to 800 MWe by 2000 . Most of the increase is due to higher load forecasts for public utilities. These findings are published in BPA's 1991 Loads and Resources Study, also known as the Whitebook.

The Whitebook contains load forecasts for the next 20 years and lists existing resources in the federal system and the region as a whole. It does not include projected future generation and conservation programs -- the $1,100 \mathrm{MW}$ BPA plans to acquire by the year 2000 will be counted in future Whitebooks only after contracts are signed.

The 1991 Whitebook includes the Trojan nuclear power plant as a firm resource for the next 20 years; however, it has since been announced that the plant will be retired in 1996. Future generation capacity will likely be less than projected by the Whitebook. Estimates for hydroelectric generation have been modified to reflect changes in constraints that have evolved over the past two years. Higher flows to accommodate fish migration mean the system now has more capacity in summer, but lower water levels at Grand Coulee in winter will mean less capacity at that time of year. The Whitebook does not include changes in flows for fish as described by the
Northwest Power Planning Council in the amended fish and wildlife program released in December 1991.

Source: Geothermal Resources Council Bulletin 2/92 and Nuclear News 12/92

\section{BPA'S GEOTHERMAL PILOT PROJECTS SELECTED}

Bonneville Power Administration (BPA) announced on December 19, 1991, that it would begin discussions on three geothermal pilot projects selected from seven proposed to BPA in September.

The selection begins the planning process at three of the most promising geothermal energy sites in the Northwest and northern California. Each project will undergo a public and environmental review that could take about three years to complete before any development begins.

BPA wants to hear concerns from anyone interested in these projects at an early state of project planning. Early public discussion can help them find constructive solutions if there are siting issues.

The projects chosen for further discussion are:

- Newberry Volcano near the Newberry National Monument in central Oregon. The project was proposed by California Energy Company, Omaha, Nebraska, with the Eugene Water and Electric Board, Eugene, Oregon, as its utility partner. 
- Glass Mountain, about 50 miles south of Klamath Falls in northern California, proposed by LoS Angeles-based Unocal.

- Vale, Oregon, 15 miles west of the Oregon-Idaho border, proposed by TransPacific Geothermal Corporation based in Oakland, California.

Each project could initially produce an average of 25 to $30 \mathrm{MWe}$. The cost of the energy will be negotiated, but is expected to be less than the cost of a coal plant. Geologists believe each site has the potential for at least $100 \mathrm{MWe}$ of energy. The projects would begin producing power in 1995 or 1996.

BPA's solicitation called for a utility. partner for each project to share the costs and power outputs. They are optimistic that utility partners will be found for the Glass Mountain and Vale proposals.

BPA called geothermal energy one of the most promising of the undeveloped renewable resources in the Pacific Northwest. BPA is excited about its potential for helping to meet future energy needs.

In addition to the three geothermal pilot projects, BPA has short-listed a geothermal project proposed for Lake City, California. The developer, TransPacific Geothermal, responded to BPA's all-resources request for proposals. TransPacific is negotiating with BPA to supply 10-30 MWe of power from the site.

Source: Geothermal Resources Council Bulletin 1/92

The key to the abbreviations used in the power plant tables is as follows:

\section{Plant Type}

$\begin{array}{lll}\text { DS } & - & \text { Dry Steam } \\ \text { DF } & - & \text { Dual Flash } \\ \text { SF } & - & \text { Single Flash } \\ \text { B } & - & \text { Binary }\end{array}$

$\underline{\text { Utilities }}$

\begin{tabular}{|c|c|c|}
\hline BPA & & Bonneville Power Administration \\
\hline CCPA & & Central California Power Agency \\
\hline HELCO & & Hawaii Electric Light Co. \\
\hline IID & & Imperial Irrigation District \\
\hline LADWP & & $\begin{array}{c}\text { Los Angeles Department of } \\
\text { Water and Power }\end{array}$ \\
\hline NCPA & & Northern California Power Agency \\
\hline PG\&E & & Pacific Gas and Electric Co. \\
\hline PP\&L & - & Pacific Power and Light Co. \\
\hline PSP\&L & & Puget Sound Power \& Light Co. \\
\hline SCE & & Southern California Edison \\
\hline SDG\&E & & San Diego Gas and Electric Co. \\
\hline SPP & & Sierra Pacific Power Co. \\
\hline UPD & & $\begin{array}{l}\text { Utah Power Division of } \\
\text { Pacific Corp. }\end{array}$ \\
\hline
\end{tabular}


GEOTHERMAL ELECTRIC POWER PLANTS OPERATIONAL, UNDER CONSTRUCTION, AND PLANNED IN THE UNTTED STATES

(Hot Water Plants)

\begin{tabular}{|c|c|c|c|c|c|c|c|}
\hline $\begin{array}{l}\text { LOCATION } \\
\text { (State and KGRA) }\end{array}$ & $\begin{array}{l}\text { PLANT } \\
\text { NAME }\end{array}$ & TYPE & $\begin{array}{l}\text { FIELD } \\
\text { DEVELOPER }\end{array}$ & $\begin{array}{l}\text { PLANT } \\
\text { OWNER }\end{array}$ & UTHLTY & $\begin{array}{l}\text { RATED } \\
\text { CAPACITY } \\
\text { (MW) }\end{array}$ & $\begin{array}{c}\text { YEAR } \\
\text { ON LINE }\end{array}$ \\
\hline \multicolumn{8}{|l|}{ ALASKA } \\
\hline & Unalaska & TBD & OESI & $\begin{array}{l}\text { Alaska Energy } \\
\text { Authority }\end{array}$ & TBD & 12 & 1995 \\
\hline \multicolumn{8}{|l|}{ CALIFORNIA } \\
\hline Brawley & & & SEE SALTON SEA & & & & \\
\hline \multirow[t]{6}{*}{ Coso Hot Springs } & $\begin{array}{l}\text { Navy Plant } \\
\text { No. 1, Units } \\
\text { No. 1, 2, \& } 3\end{array}$ & DF & Califomia Energy & $\begin{array}{l}\text { California } \\
\text { Energy }\end{array}$ & SCE & 80 & $1987-1988$ \\
\hline & $\begin{array}{l}\text { BLM East } \\
\text { (Units 1\&2) }\end{array}$ & DF & California Energy & $\begin{array}{l}\text { Califomia } \\
\text { Energy }^{2}\end{array}$ & SCE & 48 & 1988 \\
\hline & BLM West & DF & California Energy ${ }^{a}$ & $\begin{array}{l}\text { Califomia } \\
\text { Energy }\end{array}$ & SCE & 28 & 1989 \\
\hline & $\begin{array}{l}\text { Navy Plant } \\
\text { No. } 2 \text {, Units } \\
\text { No. } 4,5, \& 6\end{array}$ & DF & California Energy ${ }^{a}$ & $\begin{array}{l}\text { California } \\
\text { Energy }^{\mathrm{a}}\end{array}$ & SCE & 80 & 1989 \\
\hline & NA & DF & $\begin{array}{l}\text { Los Angeles Dept. } \\
\text { of Water and Power } \\
\text { (LADWP) }\end{array}$ & LADWP & LADWP & 50 & 1996 \\
\hline & NA & DF & $\begin{array}{l}\text { Los Angeles Dept. } \\
\text { of Water and Power } \\
\text { (LADWP) }\end{array}$ & LADWP & LADWP & 100 & 2000 \\
\hline \multirow[t]{2}{*}{ East Mesa } & $\begin{array}{l}\text { GEM } 1 \text { (formerly } \\
\text { B.C. McCabe) }\end{array}$ & B & $\begin{array}{l}\text { GEO } \\
\text { Operator/Mission }^{\text {b,c }}\end{array}$ & GEO/Mission $^{c}$ & SCE & $12.5^{\mathrm{d}}$ & 1980 \\
\hline & Ormesa I & B & OESI & OESI & SCE & 24 & 1986 \\
\hline
\end{tabular}

a Various venture partners are involved in all California Energy Coso plants Magma Power original owner

c Mission Energy, a subsidiary of SCE

d Enlarged from $10 \mathrm{MWe}$ 


\begin{tabular}{|c|c|c|c|c|c|c|c|}
\hline \multicolumn{8}{|c|}{$\begin{array}{l}\text { GEOTHERMAL ELECTRIC POWER PLANTS OPERATIONAL, UNDER CONSTRUCTION, AND PLANNED } \\
\text { IN THE UNITED STATES } \\
\text { (Hot Water Plants) }\end{array}$} \\
\hline $\begin{array}{l}\text { LOCATION } \\
\text { (State and KGRA) }\end{array}$ & $\begin{array}{l}\text { PLANT } \\
\text { NAME }\end{array}$ & TYPE & $\begin{array}{l}\text { FIELD } \\
\text { DEVELOPER }\end{array}$ & $\begin{array}{l}\text { PLANT } \\
\text { OWNER }\end{array}$ & UTILITY & $\begin{array}{l}\text { RATED } \\
\text { CAPACITY } \\
\text { (MW) }\end{array}$ & $\begin{array}{c}\text { YEAR } \\
\text { ON LINE }\end{array}$ \\
\hline \multicolumn{8}{|l|}{ CALIFORNIA (Cont'd) } \\
\hline & Ormesa II & B & $\begin{array}{l}\text { OESI/Harbert } \\
\text { International }\end{array}$ & OESI/Harbert & SCE & 17 & 1988 \\
\hline & Ormesa IE & B & OESI & OESI & SCE & 8 & 1988 \\
\hline & Ormesa IH & B & OESI & OESI/Harbert & SCE & 6 & 1989 \\
\hline & GEM 2 & DF & GEO/Mission ${ }^{c}$ & GEO/Mission ${ }^{c}$ & SCE & 37 & 1989 \\
\hline Glass Mountain & Unocal I & DF & Unocal & Unocal & $\mathrm{BPA}^{\mathrm{e}}$ & $10-30$ & 1996 \\
\hline \multirow[t]{2}{*}{ Heber } & $\begin{array}{l}\text { Heber Dual } \\
\text { Flash Power } \\
\text { Plant }\end{array}$ & DF & $\begin{array}{l}\text { Chevron } \\
\text { Resources Co. }\end{array}$ & $\begin{array}{l}\text { Calpine } \\
\text { Corp./ERC } \\
\text { International }\end{array}$ & SCE & 47 & 1985 \\
\hline & $\begin{array}{l}\text { Heber Binary } \\
\text { Project } 8\end{array}$ & B & Chevron & To be sold by SDG\&E & SDG\&E & 45 & 1985 \\
\hline \multirow[t]{4}{*}{ Mono-Long Valley } & $\begin{array}{l}\text { Mammoth } \\
\text { Pacific (MP) } \\
\text { Unit } 1\end{array}$ & B & Pacific Energy ${ }^{h}$ & Pacific Energy ${ }^{h}$ & SCE & 7 & 1984 \\
\hline & MP Unit II & B & Pacific Energy ${ }^{h}$ & $\begin{array}{l}\text { Pacific } \\
\text { Energy }\end{array}$ & SCE & 10 & 1990 \\
\hline & MP Unit III & B & Pacific Energy ${ }^{h}$ & Pacific Energy ${ }^{h}$ & SCE & 10 & $\begin{array}{l}1994 \\
\text { (est.) }\end{array}$ \\
\hline & $\begin{array}{l}\text { Pacific Lighting } \\
\text { Energy Systems } \\
\text { (PLES) Unit I }\end{array}$ & B & Pacific Energy ${ }^{h}$ & $\begin{array}{l}\text { Pacific } \\
\text { Energy/Constellation }\end{array}$ & SCE & 10 & 1990 \\
\hline
\end{tabular}

Bonneville Power Administration Geothermal Power Project

Partnership of Dravo Corp. and Centennial Energy original owner

Demonstration plant supported by the U.S. Department of Energy; currently not in operation

h Subsidiary of Pacific Enterprises 


\begin{tabular}{|c|c|c|c|c|c|c|c|}
\hline \multirow[b]{2}{*}{$\begin{array}{l}\text { LOCATION } \\
\text { (State and KGRA) }\end{array}$} & \multicolumn{7}{|c|}{$\begin{array}{l}\text { GEOTHERMAL ELECTRIC POWER PLANTS OPERATIONAL, UNDER CONSTRUCTION, AND PLANNED } \\
\text { IN THE UNTTED STATES } \\
\text { (Hot Water Plants) }\end{array}$} \\
\hline & $\begin{array}{l}\text { PLANT } \\
\text { NAME } \\
\end{array}$ & TYPE & $\begin{array}{l}\text { FIELD } \\
\text { DEVELOPER }\end{array}$ & $\begin{array}{l}\text { PLANT } \\
\text { OWNER }\end{array}$ & UTILTTY & $\begin{array}{l}\text { RATED } \\
\text { CAPACITY } \\
\text { (MW) }\end{array}$ & $\begin{array}{c}\text { YEAR } \\
\text { ON LNE } \\
\end{array}$ \\
\hline \multicolumn{8}{|c|}{ CALIFORNIA (Cont'd) } \\
\hline \multirow[t]{3}{*}{ Salton Sea } & Salton Sea Unit 1 & $\mathbf{S F}$ & $\begin{array}{l}\text { Earth Energy } \\
\text { (acquired full field } \\
\text { ownership from } \\
\text { partners Southern } \\
\text { Pacific Land Co. } \\
\text { and Mono Power) }\end{array}$ & Earth Energy ${ }^{\mathbf{i}, \mathbf{j}}$ & SCE & 10 & 1982 \\
\hline & Unit 2 & SF & Earth Energyi & Earth Energy ${ }^{1, j}$ & SCE & $17^{k}$ & 1990 \\
\hline & Vulcan & DF & Magma/Mission ${ }^{\mathrm{e}}$ & Magma/Mission ${ }^{\mathrm{c}}$ & SCE & 32 & 1985 \\
\hline 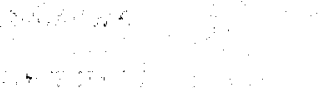 & Del Ranch & DF & Magma/Mission $^{\mathrm{c}}$ & Magma/Mission $^{c}$ & SCE & $36^{1}$ & 1988 \\
\hline & Elmore I & DF & Magma/Mission $^{\mathrm{c}}$ & Magma/Mission ${ }^{\mathbf{c}}$ & SCE & $36^{1}$ & 1988 \\
\hline & Leathers I & DF & Magma/Mission $^{\mathfrak{c}}$ & Magma/Mission ${ }^{\mathrm{c}}$ & SCE & $36^{1}$ & 1989 \\
\hline & $\begin{array}{l}\text { Magma \& } \\
\text { Expansion }^{\mathrm{m}}\end{array}$ & DF & Magma & Magma & IID & $18^{m}$ & 1993 \\
\hline 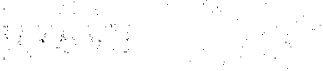 & Salton Sea Unit 3 & DF & Desert Power ${ }^{i}$ & Desert Poweri & SCE & 50 & 1989 \\
\hline Surprise Valley & Lake City Unit 1 & B & $\begin{array}{l}\text { Trans- } \\
\text { Pacific/Constellation }\end{array}$ & $\begin{array}{l}\text { Trans- } \\
\text { Pacific/Constellation }\end{array}$ & PSP\&L & 10 & 1994 \\
\hline Surprise Valley & Lake City Unit 2 & B & Trans-Pacific & Trans-Pacific & BPA & $10-30$ & TBD \\
\hline Wendel-Amedee & Wineagle Project & B & $\begin{array}{l}\text { Wineagle } \\
\text { Developers }\end{array}$ & Wineagle Developers & PG\&E & $.7^{\mathrm{n}}$ & 1985 \\
\hline
\end{tabular}

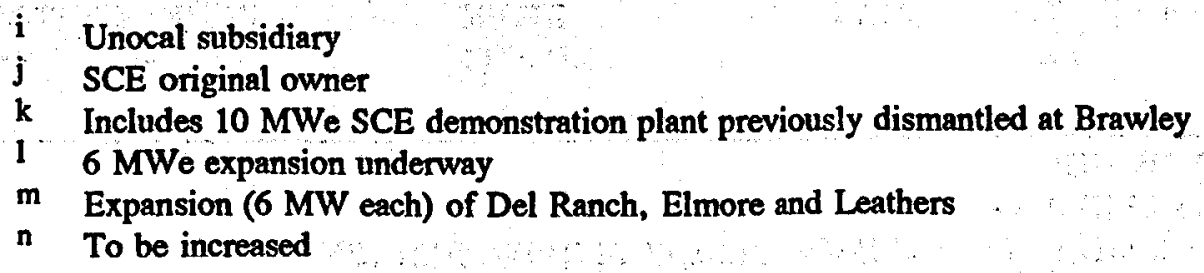




\begin{tabular}{|c|c|c|c|c|c|c|c|}
\hline \multicolumn{8}{|c|}{$\begin{array}{l}\text { GEOTHERMAL ELECTRIC POWER PLANTS OPERATIONAL, UND } \\
\text { IN THE UNITED STATES } \\
\text { (Hot Water Plants) }\end{array}$} \\
\hline $\begin{array}{l}\text { LOCATION } \\
\text { (State and KGRA) }\end{array}$ & $\begin{array}{l}\text { PLANT } \\
\text { NAME }\end{array}$ & TYPE & $\begin{array}{l}\text { FIELD } \\
\text { DEVELOPER }\end{array}$ & $\begin{array}{l}\text { PLANT } \\
\text { OWNER }\end{array}$ & UTILTY & $\begin{array}{l}\text { RATED } \\
\text { CAPACITY } \\
\text { (MW) }\end{array}$ & $\begin{array}{c}\text { YEAR } \\
\text { ON LINE }\end{array}$ \\
\hline \multicolumn{8}{|c|}{ CALIFORNIA (Cont'd) } \\
\hline & Amedec Geothermal & B & $\begin{array}{l}\text { Trans-Pacific } \\
\text { Geothermal Inc. } \\
\text { (TPG)/U.S. Energy } \\
\text { Corp. }\end{array}$ & TPGIU.S. & PG\&E & $2^{\circ}$ & 1988 \\
\hline & $\begin{array}{l}\text { Honey Lake Power } \\
\text { Facility }\end{array}$ & $\mathbf{B}^{\mathbf{P}}$ & GeoProducts Corp. & HL Power Co. & PG\&E & 309 & 1988 \\
\hline \multicolumn{8}{|l|}{ HAWAII } \\
\hline & $\begin{array}{l}\text { Puna Geothermal } \\
\text { Venture I }\end{array}$ & SF/B & OESI & OESI & HELCO & 25 & 1992 \\
\hline & $\begin{array}{l}\text { Kilauea Middle East } \\
\text { Rift }\end{array}$ & $\mathbf{S F}$. & $\begin{array}{l}\text { True Geothermal } \\
\text { Energy }\end{array}$ & $\begin{array}{l}\text { True/Mid-Pacific } \\
\text { Joint Venture }\end{array}$ & HELCO & 25 & 1995 \\
\hline \multicolumn{8}{|l|}{ NEVADA } \\
\hline Beowawe & Beowawe & DF & $\begin{array}{l}\text { California Energy } \\
\text { (originally Chevron) }\end{array}$ & $\begin{array}{l}\text { Califomia } \\
\text { Energy/Crescent Valley }^{\text {Geothermal }}\end{array}$ & SCE & 15 & 1985 \\
\hline Brady-Hazen & Desert Peak & DF & $\begin{array}{l}\text { California Energy } \\
\text { (originally Phillips; } \\
\text { more recently } \\
\text { Chevron) }\end{array}$ & $\begin{array}{l}\text { California Energy } \\
\text { (originally Chevron) }\end{array}$ & SPP & 9 & 1985 \\
\hline Brady-Hazen & Brady Hot Springs I & DF & $\begin{array}{l}\text { Brady Power } \\
\text { Partners }\end{array}$ & Brady Power Partners & SPP & 20 & 1992 \\
\hline
\end{tabular}

- Phase II will add 3 MWe

A co-generation plant using wood waste and geothermal heat; geothermal fluid used only to preheat boiler feedwater Original geothermal concept has not been abandoned; means to add it have been incorporated

SCE subsidiary 


\begin{tabular}{|c|c|c|c|c|c|c|c|}
\hline \multirow[b]{2}{*}{$\begin{array}{l}\text { LOCATION } \\
\text { (State and KGRA) }\end{array}$} & \multirow[b]{2}{*}{$\begin{array}{l}\text { PLANT } \\
\text { NAME }\end{array}$} & \multirow[b]{2}{*}{ TYPE } & \multicolumn{2}{|c|}{$\begin{array}{l}\text { N THE UNTTED STATES } \\
\text { (Hot Water Plants) }\end{array}$} & \multirow[b]{2}{*}{ UTILITY } & \multirow[b]{2}{*}{$\begin{array}{l}\text { RATED } \\
\text { CAPACITY } \\
\text { (MW) }\end{array}$} & \multirow[b]{2}{*}{$\begin{array}{c}\text { YEAR } \\
\text { ON LINE }\end{array}$} \\
\hline & & & $\begin{array}{l}\text { FIELD } \\
\text { DEVELOPER }\end{array}$ & $\begin{array}{l}\text { PLANT } \\
\text { OWNER }\end{array}$ & & & \\
\hline \multicolumn{8}{|l|}{ NEVADA (Cont'd) } \\
\hline \multirow[t]{2}{*}{ Darrough Hot Springs } & Fishlake I & TBD & Magma & Magma & SCE & 14 & 1995 \\
\hline & Falton Navy Facility & TBD & TBD & TBD & TBD & 160 & $\begin{array}{l}1996 \\
\text { (est.) }\end{array}$ \\
\hline \multirow[t]{2}{*}{ Dixie Valley } & Oxbow & DF & $\begin{array}{l}\text { Oxbow Goothermal } \\
\text { (originally Sunedco; } \\
\text { then Trans-Pacific) }\end{array}$ & Oxbow & SCE & 50 & 1988 \\
\hline & Caithness I & DF & Caithness & Caithness & SCE & 19 & 1995 \\
\hline \multirow[t]{2}{*}{ Ryepatch } & Ryepatch A & B & OESI & OESI & SPP & 13 & 1993 \\
\hline & Ryepatch B & B & OESI & OESI & SPP & 13 & TBD \\
\hline \multirow[t]{3}{*}{ San Emidio Desert } & $\begin{array}{l}\text { Empire Geothermal } \\
\text { Project }\end{array}$ & B & OESI & Empire Geothermal & SPP & 3 & 1987 \\
\hline & San Emidio I & B & $\begin{array}{l}\text { San Emidio } \\
\text { Resources }\end{array}$ & San Emidio Resources & SPP & 5 & 1994 \\
\hline & San Emidio II & B & $\begin{array}{l}\text { San Emidio } \\
\text { Resources }\end{array}$ & San Emidio Resources & SPP & 22 & 1994 \\
\hline \multirow[t]{4}{*}{ Steamboat Springs } & $\begin{array}{l}\text { Steamboat Geo- } \\
\text { thermal I }\end{array}$ & B & $\begin{array}{l}\text { Geothermal } \\
\text { Development } \\
\text { Associates } \\
\text { (GDA/OESI) }\end{array}$ & $\begin{array}{l}\text { Far West Electric } \\
\text { Energy Fund, Ltd. }\end{array}$ & SPP & 6.8 & 1986 \\
\hline & $\begin{array}{l}\text { Steamboat Geothermal } \\
\text { IA }\end{array}$ & B & OESI/GDA & Far West & SPP & 1.2 & 1989 \\
\hline & Yankee/Caithness & $\mathbf{S F}$ & Caithness/Sequa & Caithness/Sequa & SPP & $12^{\mathrm{s}}$ & 1988 \\
\hline & Caithness Binary & B & Caithness & Caithness & SPP & 8 & 1993 \\
\hline
\end{tabular}

s An $8 \mathrm{MWe}$ binary unit being added 


\begin{tabular}{|c|c|c|c|c|c|c|c|}
\hline \multicolumn{8}{|c|}{$\begin{array}{l}\text { GEOTHERMAL ELECTRIC POWER PLANTS OPERATIONAL, UNDER CONSTRUCTION, AND PLANNED } \\
\text { IN THE UNITED STATES } \\
\text { (Hot Water Plants) }\end{array}$} \\
\hline $\begin{array}{l}\text { LOCATION } \\
\text { (State and KGRA) }\end{array}$ & $\begin{array}{l}\text { PLANT } \\
\text { NAME }\end{array}$ & TYPE & $\begin{array}{l}\text { FIELD } \\
\text { DEVELOPER }\end{array}$ & $\begin{array}{l}\text { PLANT } \\
\text { OWNER }\end{array}$ & UTHITY & $\begin{array}{l}\text { RATED } \\
\text { CAPACITY } \\
\text { (MW) }\end{array}$ & $\begin{array}{c}\text { YEAR } \\
\text { ON LINE }\end{array}$ \\
\hline \multirow[t]{2}{*}{ NEVADA (Cont'd) } & Steamboat 2 & B & $\begin{array}{l}\text { Steamboat } \\
\text { Development }\end{array}$ & Steamboat Development & SPP & 12 & 1992 \\
\hline & Steamboat 3 & B & $\begin{array}{l}\text { Steamboat } \\
\text { Development }\end{array}$ & Steamboat Development & SPP & 12 & 1993 \\
\hline \multirow[t]{3}{*}{ Stillwater/Soda Lake } & $\begin{array}{l}\text { Soda Lake Geothermal } \\
\text { Project }\end{array}$ & B & Chevron & $\begin{array}{l}\text { Institutional Investors } \\
\text { (OESI Operator) }\end{array}$ & SPP & 2.7 & 1987 \\
\hline & $\begin{array}{l}\text { Stillwater Geothermal } \\
\text { I Project }\end{array}$ & B & OESI & $\begin{array}{l}\text { OESI/Constellation } \\
\text { Development/Chrysler } \\
\text { Capital }\end{array}$ & SPP & 13 & 1989 \\
\hline & Soda Lake II & B & Amor & OESI & SPP & 13 & 1990 \\
\hline Wabuska $^{t}$ & Wabuska & B & Tad's Enterprises & Tad's Enterprises & SPP & 1.5 & 1984 \\
\hline \multicolumn{8}{|l|}{ OREGON } \\
\hline Newberry Crater & NÁ & DF & Califormia Energy & California Energy & $\begin{array}{c}\text { Eugene } \\
\text { Water \& } \\
\text { Electric; } \\
\text { BPA }^{\mathrm{e}}\end{array}$ & $10-30$ & 1996 \\
\hline Vale & NA & DF & Transpacific & Transpacific & $\mathrm{BPA}^{\mathrm{e}}$ & $10-30$ & 1996 \\
\hline UTAH & & & & $\cdots$ & & & \\
\hline Roosevelt Hot Springs & Blundell I & SF & $\begin{array}{l}\text { California Energy } \\
\text { Co. (originally } \\
\text { Phillips; } \\
\text { subsequently } \\
\text { Chevron) }\end{array}$ & $\begin{array}{l}\text { Utah Power Div. } \\
\text { (UPD) of PacificCorp }\end{array}$ & UPD & 20 & 1984 \\
\hline
\end{tabular}




\begin{tabular}{|c|c|c|c|c|c|c|c|}
\hline \multicolumn{8}{|c|}{$\begin{array}{l}\text { GEOTHERMAL ELECTRIC POWER PLANTS OPERATIONAL, UNDER CONSTRUCTION, AND PLANNED } \\
\text { IN THE UNITED STATES } \\
\text { (Hot Water Plants) }\end{array}$} \\
\hline $\begin{array}{l}\text { LOCATION } \\
\text { (State and KGRA) }\end{array}$ & $\begin{array}{l}\text { PLANT } \\
\text { NAME }\end{array}$ & TYPE & $\begin{array}{l}\text { FIELD } \\
\text { DEVELOPER }\end{array}$ & $\begin{array}{l}\text { PLANT } \\
\text { OWNER }\end{array}$ & UTILIT & $\begin{array}{l}\text { RATED } \\
\text { CAPACITY } \\
\text { (MW) }\end{array}$ & $\begin{array}{c}\text { YEAR } \\
\text { ON LINE }\end{array}$ \\
\hline \multicolumn{8}{|l|}{ UTAH (Cont'd) } \\
\hline \multirow[t]{3}{*}{ Cove Fort-Sulphurdale } & $\begin{array}{l}\text { Cove Fort Geothermal } \\
\text { No. } 1\end{array}$ & $\mathbf{B}$ & Mother Earth & City of Provo & $\begin{array}{l}\text { Utah } \\
\text { Municipal } \\
\text { Power } \\
\text { Agency }\end{array}$ & 3 & 1985 \\
\hline & Cove Fort Steam Plant & DS & Mother Earth & City of Provo & $\begin{array}{l}\text { Provo } \\
\text { Power Co. }\end{array}$ & $2^{2}$ & 1988 \\
\hline & $\begin{array}{l}\text { Cove Fort Steam } \\
\text { No. } 2\end{array}$ & DS & Mother Earth & City of Provo & $\begin{array}{l}\text { Provo } \\
\text { Power Co. }\end{array}$ & 8 & 1989 \\
\hline
\end{tabular}

$\underset{\sigma}{\omega}$ 


\begin{tabular}{|c|c|c|c|c|c|}
\hline \multicolumn{6}{|c|}{$\begin{array}{l}\text { GEOTHERMAL ELECTRIC POWER PLANTS OPERATIONAL, UNDER CONSTRUCTION, AND PLANNED } \\
\text { IN THE UNITED STATES } \\
\text { (Dry Steam Plants at The Geysers) }\end{array}$} \\
\hline $\begin{array}{l}\text { PLANT } \\
\text { NAME }\end{array}$ & $\begin{array}{l}\text { FIELD } \\
\text { DEVELOPER }\end{array}$ & PLANT OWNER & UTILITY & $\begin{array}{c}\text { CAPACITY } \\
\text { (MW) }\end{array}$ & $\begin{array}{l}\text { YEAR } \\
\text { ON LINE }\end{array}$ \\
\hline PG\&E Unit No. $1^{a}$ & UNOCAL/Magma/Thermal & PG\&E & PG\&E & 11 & 1960 \\
\hline No. $2^{\mathrm{a}}$ & " & " & " & 13 & 1963 \\
\hline No. $3^{\mathrm{a}}$ & " & " & " & 27 & 1967 \\
\hline No. $4^{\mathrm{a}}$ & " & " & " & 27 & 1968 \\
\hline No. 5 & " & " & " & 53 & 1971 \\
\hline No. 6 & $"$ & " & " & 53 & 1971 \\
\hline No. 7 & " & " & " & 53 & 1972 \\
\hline No. 8 & $"$ & " & " & 53 & 1972 \\
\hline No. 9 & $n$ & " & " & 53 & 1973 \\
\hline No. 10 & " & " & " & 53 & 1973 \\
\hline No. 11 & " & " & " & 106 & 1975 \\
\hline No. 12 & $"$ & " & " & 106 & 1979 \\
\hline No. $15^{2}$ & $\begin{array}{l}\text { Geothermal Resources } \\
\text { International }\end{array}$ & $"$ & " & 59 & 1979 \\
\hline No. 13 & $\begin{array}{l}\text { Santa Rosa Geothermal } \\
\text { Co. }\end{array}$ & " & " & 133 & 1980 \\
\hline No. 14 & $\begin{array}{l}\text { UNOCAL/Magma/Thermal } \\
\text { (Natomas) }\end{array}$ & " & " & 109 & 1980 \\
\hline
\end{tabular}

a Retired

b Formed by Calpine Corp. and Freeport-McMoran as new owner of leases and steam supply operations; originally Aminoil properties 


\begin{tabular}{|c|c|c|c|c|c|}
\hline \multicolumn{6}{|c|}{$\begin{array}{l}\text { GEOTHERMAL ELECTRIC POWER PLANTS OPERATIONAL, UNDER CONSTRUCTION, AND PLANNED } \\
\text { IN THE UNTED STATES } \\
\text { (Dry Steam Plants at The Geysers) }\end{array}$} \\
\hline $\begin{array}{l}\text { PLANT } \\
\text { NAME }\end{array}$ & $\begin{array}{l}\text { FIELD } \\
\text { DEVELOPER }\end{array}$ & PLANT OWNER & UTUTTY & $\begin{array}{l}\text { CAPACITY } \\
\text { (MW) }\end{array}$ & $\begin{array}{l}\text { YEAR } \\
\text { ON LINE }\end{array}$ \\
\hline No. 17 & $\begin{array}{l}\text { UNOCAL/Magma/Thermal } \\
\text { (Natomas) }\end{array}$ & PG\&E & PG\&E & 110 & 1982 \\
\hline No. 18 & $\begin{array}{l}\text { UNOCAL/Magma/Thermal } \\
\text { (Natomas) }\end{array}$ & PG\&E & PG\&E & 110 & 1983 \\
\hline SMUDGEO No. 1 & Santa Rosa Geothermal Co. & $\begin{array}{l}\text { Sacramento } \\
\text { Municipal Utility } \\
\text { District }\end{array}$ & SMUD & 72 & 1983 \\
\hline NCPA No. $1^{\mathrm{c}}$ & $\begin{array}{l}\text { Northern Calif. Power } \\
\text { Agency (originally Grace } \\
\text { Geothermal) }\end{array}$ & NCPA & NCPA & 110 & 1983 \\
\hline $\begin{array}{l}\text { Santa Fe } \\
\text { Geothermal } 1\end{array}$ & $\begin{array}{l}\text { Santa Fe Geothermal } \\
\text { (originally Occidental) }\end{array}$ & Santa Fe Geothermal & PG\&E & 80 & 1984 \\
\hline Bottle Rock $^{d}$ & $\mathrm{NCPA}$ & $\begin{array}{l}\text { Calif. Dept of Water } \\
\text { Resources }\end{array}$ & $\begin{array}{l}\text { Calif. Dept of Water } \\
\text { Resources }\end{array}$ & 55 & 1984 \\
\hline NCPA No. $2^{c}$ & NCPA & NCPA & NCPA & 110 & 1985 \\
\hline PG\&E Unit No. 16 & Santa Rosa Geothermal Co. ${ }^{b}$ & PG\&E & PG\&E & 110 & 1985 \\
\hline No. 20 & $\begin{array}{l}\text { UNOCAL/Thermal } \\
\text { (Diamond Shamrock) }\end{array}$ & PG\&E & PG\&E & 110 & 1985 \\
\hline Cold Water Creek & $\begin{array}{l}\text { Cold Water Creek Operating } \\
\text { Co. }\end{array}$ & $\mathrm{CCPA}^{\mathrm{e}}$ & $\mathrm{CCPA}^{\mathrm{f}}$ & 124 & 1988 \\
\hline
\end{tabular}

C Originally NCPA Nos. 2 and 3

d Closed

e Plant ownership divided among Sacramento Municipal Utility District (SMUD), Modesto Irrigation District (MID), and the City of Santa Clara

f The new partnership of Calpine Corp. and Freeport-McMoRan owns both field and power plant operations; originally Geysers Geothermal properties 


\begin{tabular}{|c|c|c|c|c|c|}
\hline \multicolumn{6}{|c|}{$\begin{array}{c}\text { GEOTHERMAL ELECTRIC POWER PLANTS OPERATIONAL, UNDER CONSTRUCTION, AND PLANNED } \\
\text { IN THE UNITED STATES } \\
\text { (Dry Steam Plants at The Geysers) }\end{array}$} \\
\hline $\begin{array}{l}\text { PLANT } \\
\text { NAME }\end{array}$ & $\begin{array}{c}\text { FIELD } \\
\text { DEVELOPER }\end{array}$ & PLANT OWNER & UTLITY & $\begin{array}{l}\text { RATED } \\
\text { CAPACITY } \\
\text { (MW) }\end{array}$ & $\begin{array}{l}\text { YEAR } \\
\text { ON LINE }\end{array}$ \\
\hline Bear Canyon Creek & $\begin{array}{l}\text { Santa Rosa Geothermal } \\
\text { Co. }\end{array}$ & Santa Rosa ${ }^{f}$ & PG\&E & 22 & 1988 \\
\hline West Ford Flat & Santa Rosa Geothermal Co. ${ }^{f}$ & Santa Rosa ${ }^{f}$ & PG\&E & 29 & 1988 \\
\hline $\begin{array}{l}\text { Joseph W. Aldlin } \\
\text { Power Plant }\end{array}$ & $\begin{array}{l}\text { Geothermal Energy } \\
\text { Partners\& }\end{array}$ & $\begin{array}{l}\text { Geothermal Energy } \\
\text { Partners/Cloverdale } \\
\text { Geothermal } \\
\text { Partners }\end{array}$ & PG\&E & 20 & 1989 \\
\hline
\end{tabular}


DOEIINDUSTRY COST SHARING PROOF-OF-CONCEPT SLIMHOLE DRILLING PROJECTS

The objective of the DOE geothermal drilling $R \& D$ is to reduce the cost of drilling and completing geothermal wells specifically, to reduce by 50 percent the up-front exploration and reservoir assessment costs required to obtain financing for geothermal power plant development. The deep, production-size wells used for these purposes with today's technology cost from $\$ 1.5$ to $\$ 3.5$ million each, representing prohibitive costs for many developers or potential developers. In support of this cost-reduction objective, and at the request of the Hard Rock Penetration industry review panel, the Sandia National Laboratory has initiated DOE work in slimhole drilling for geothermal exploration and reservoir assessment. This effort will be carried out in a cooperative DOE/industry program that will also support development of geothermal energy in the Pacific Northwest to meet utility needs.

The technology needs for geothermal application of slimhole drilling lie in three areas:

- proof-of-concept experiments to determine if sufficient reservoir data can be obtained from slimholes

- development of reservoir evaluation techniques to optimize use of slimholes
- slimhole drilling technology development to optimize current hardware and techniques for the geothermal environment.

Sandia's approach to these needs is to, first, evaluate the concept through review and documentation of Japanese slimhole data, and then to drill and test, in partnership with industry, slimholes at several locations where reservoir parameters are known from large hole flow tests. By comparing directly the data developed from the same formation by large and small wells, it can be determined whether sufficient data can be obtained with the far less costly wells.

One cost-shared project has been initiated at Steamboat Hills, Nevada, with Far West Capital using slimhole flow tests. and multiwell tracer tests. Other DOE/industry partnerships are under discussion which would involve three geothermal sites in the Cascades in northern California and Oregon.

The importance of these sites is indicated by conservative estimates that the geothermal resources of the Pacific - Northwest can support as much as 5,000 MWe of power generation capacity. The Northwest Power Planning Council predicts a power shortage in the area in the 1990s of several hundred megawatts, and area utilities are looking to geothermal energy as a cost-effective, near-term resource and are supporting small demonstration projects. However, for development to expand beyond the handful of sites that have already been subjected to costly exploratory drilling, the use of the resource 
will be greatly curtailed unless these costs are reduced.

\section{ADVANCES REPORTED IN SEVERAL GEOTHERMAL DRILLING TECHNOLOGIES}

In addition to its efforts in slimhole research to develop cost-effective geothermal exploration and reservoir assessment techniques, the DOE drilling $R \& D$ at Sandia includes projects on lost circulation control, rock penetration mechanics, and instrumentation. Sandia spokesmen have reported advances over the last year in all of the technologies under investigation.

A new flow meter -- called the Rolling Float Meter - to accurately measure drilling fluid outflow was tested extensively during drilling of the Long Valley Exploration Well in California, a joint DOE/California Energy Commission project. Results show that this meter is rugged, reliable, and can provide useful measurements of small differences in fluid inflow and outflow rates. By providing early indications of fluid gain or loss, improved control of blowout and lost circulation problems during geothermal drilling can be expected. The oil and gas industry is also very interested in the rolling float meter to identify gas kicks and outflow rates.
In other tests at the Long Valley well, a technique for measuring downhole fracture apertures with an acoustic borehole televiewer demonstrated the benefits of proper signal conditioning to identify and measure fractures of potential significance in lost circulation or well production. In addition, lost circulation control was advanced by development of a concept of a downhole injector for injecting a two-component, fast-setting cementitious mud, for which a DOE patent application has been filed. The significance of these achievements is that lost circulation accounts for a very large percentage of the high costs of geothermal drilling and well completion.

Advancements in logging of geothermal wells will provide an as yet unused tool for invaluable downhole measurements important to the development and maintenance of geothermal fields -- e.g., guidance in well placement. The Sandia approach to instrumentation for hightemperature wells is to use a downhole memory unit that stores the data in a computer system. Since these tools are completely self-contained, they are readily deployed using the slick line found on most drilling locations. They have proven to be rugged, and a minimum training program is required for operator personnel. The utility of these tools has been demonstrated to industry. 


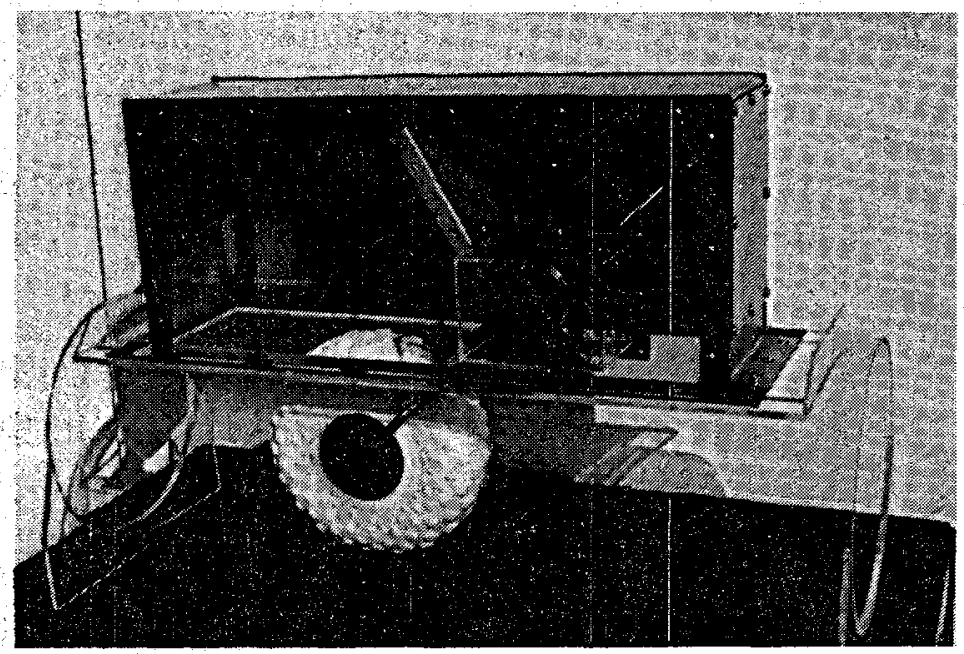

Rolling Float Meter

In the absence of a commercially available flowmeter to meet all the requirements of lost circulation detection in geothermal wells, Sandia has developed a device called the Rolling Float Meter. It can advise the driller of lost circulation as it occurs, the magnitude of the loss, its location, and possible treatment.

Sandia has also reported that the fundamental theory of acoustic telemetry in drill strings - a dream of the drilling industry for 50 years . has been significantly advanced through field experimentation and analysis. The advances include, among others:

- characterization of sound speeds and signal distortion within the drilling passbands

- identification of the different frequency-domain patterns associated with echoes and tool joints
- identification of the underlying signal attenuation mechanisms.

Major contributions to the drilling advancements have been made by the materials research of Brookhaven National Laboratory. These include BNL-developed, phosphate-modified calcium aluminum cements, which are stable in $300^{\circ} \mathrm{C}$ $\left(572^{\circ} \mathrm{F}\right)$ brines and resistant to chemical attack by carbon dioxide, and other advanced cements containing fibers or particulates for lost circulation control when large fissures are encountered. 


\section{DEEP WELL PLANNED ON FLANKS OF NEWBERRY VOLCANO}

Vulcan Power Company spudded the first deep geothermal resource confirmation well on the west flank of Newberry Volcano in Oregon in the fall of 1992 . The deep well is located where temperaturegradient holes have encountered temperatures up to $170^{\circ} \mathrm{C}\left(338^{\circ} \mathrm{F}\right)$ at a depth of $-2,400$ feet. Geophysical studies and projection of temperature gradients in the area suggest that commercial geothermal resources may exist at depths of 5,416 to 8,890 feet. The summit caldera of Newberry volcano is the location of one of the hottest shallow geothermal wells in the continental United States. That research well, drilled by the U.S. Geological Survey in 1978-1981, reached a temperature of $265^{\circ} \mathrm{C}\left(509^{\circ} \mathrm{F}\right)$ at a depth of only 3,100 feet. The caldera of Newberry volcano is in the newly created Newberry National Volcanic Monument where no geothermal drilling is allowed, but geothermal development can take place on the flanks of the volcano outside the boundaries of the Monument.

Vulcan has completed a joint-venture partnership agreement with the family interests of Lawrence Barker, a large private international resource developer, providing for the financing of Newberry resource confirmation wells, reservoir con- firmation well testing, and other costs of its Newberry leasehold. This partnership provides funding for a three-well exploration project at Newberry.

Source: Vulcan Power Co. Press Release 6/18/92

\section{CALPINE CORP. ACQUIRES GRACE GEOTHERMAL LEASES}

On April 29, 1992, Calpine Corporation announced that it had acquired the development rights to 9,128 acres (four leases) of geothermal properties at Coso Hot Springs in Southern California from Sterling Grace Capital. Management, Inc. These four leases are contiguous to and south of the Los Angeles Department of Water and Power (DWP) geothermal leases. Calpine is currently negotiating a contract to operate DWP's geothermal resources in the Coso area. The Grace properties will provide an additional resource area to fulfill DWP's plan for up to $150 \mathrm{MWe}$ of geothermal power.

If sufficient reserves are proven, the Grace properties could also be used to supply power to other utilities. Calpine owns an interest in and operates several geothermal power plants and steam fields totalling in excess of $350 \mathrm{MWe}$, as well as 149 MWe of gas-fired cogeneration facilities.

Source: Geothermal Resources Council Bulletin 5/92 
MAGIA ADDMG TO GEOTHEMAL

MAGMA ADDING TO GEOTHERMAL RESOURCE BASE IN RESPONSE TO MARKET OPPORTUNITIES

In response to current estimates of new California power demand by 2001, Magma Power has initiated an accelerated program of geothermal resource acquisition; exploration, and development. During 1991, the company acquired leases on 32,914 acres in the East Brawley KGRA and the Truckhaven Area, both in Imperial Valley, California, from FreeportMacMoRan, bringing its total California and Nevada leaseholds to 81,169 acres. It is estimated that during $1992 \$ 10$ million will be spent in exploration and development.

Magma owns a 75 percent interest in the Truckhaven leases, with the remaining 25 percent owned by Unocal. Due to the lower temperature and more benign nature of the fluids in this area, a binary plant is planned. At the East Brawley KGRA, where Magma is sole owner of the acquired leases, the fluids are similar to those used by Magma's Salton Sea plants and will be developed with flash plants.

Previously, Magma acquired an interest in 21,600 acres of geothermal leases at the Fish Lake geothermal resource area in Esmeralda County, Nevada, from GeoEnergy Partners - 1983 Ltd. (GEO '83). This transaction also included an $\mathrm{SO} 4$ contract to supply power to Southern California Edison, and Magma is installing a 16 MWe plant. (See INDUSTRY SCENE for details.)
Source: Magma Power Co. 1991 Annual Report to Shareholders

\section{MAGMA POWER'S USE OF "HIP. TRIPPER" DEVICE PERMITS CONSIDERABLE COST SAVINGS IN WELL MANAGEMENT}

A key to the proper maintenance of geothermal wells, and thus optimum productivity, is a well's production liner. By replacing traditional well management practices with the use of a device known as the "hip-tripper," Magma Power is achieving considerable cost savings.

Since the well liner is subject to both corrosion and erosion, it must be periodically replaced. Extending the life of the liner, thereby decreasing the frequency of well workovers, is critical to the economics of the well. Occasionally, solids in the geothermal fluid can adhere to the walls of the liner and constrict its flow before the liner is scheduled for replacement. One solution is to pull the liner early, but replacement requires that the brine flow be stopped, often resulting in plant operation below its optimum level.

Magma Power has thus adopted an alternative, less expensive and less disruptive procedure utilizing the "hiptripper" at its Salton Sea wells. This device consists of a drill with a starshaped, rotating bit that travels down the well, powered by nitrogen, while the well is still flowing. As the bit travels through the liner, it removes the accumulated solids which are then carried out of the well by 
the brine flow and directed to storage tanks.

The advantages of this approach are numerous. Continued well flow results in less disruption to operations and in considerable cost savings. For example, the cost of pulling and replacing the pipe can be more than 15 to 20 times the cost of running the hip-tripper. Equally important, hip-tripper operations can be completed within several days rather than the several weeks required to rework a production well. And, the cleaner pipe allows for dramatically improved flow and well production.

Source: Magma Power Co. 1991 Annual Report to Shareholders

\section{GOVERNMENT/INDUSTRY CO- OPERATION TO REDUCE GHP DRILLING COSTS}

Sandia has teamed with the National Rural Electric Cooperative Association (NRECA) to investigate possible improvements in methods for loop installation for geothermal heat pumps. Currently, loop installation costs are on the order of $\$ 2,000$ to $\$ 4,000$ per residence, and this high cost limits market penetration.

Traditional installation methods utilize trenching or drilled vertical holes. More innovative methods are needed to reduce costs and permit loop installation on smaller urban lots. One technique being considered is directional horizontal boring under homes. Other ideas based on the use of small mining-type drills and advancing water well drilling equipment have been proposed.

Phase I of the Sandia/NRECA effort will evaluate existing small drilling systems that could be used for loop installation. A report of this evaluation will be published describing existing hardware, modifications needed, and estimated installation costs. Phase II. will select one or two promising small drilling systems, make required modifications, test in a known test range; and then conduct real installations at NRECA sites.

\section{NEW LEASE ROYALTY RULES ISSUED BY MMS}

The Minerals Management Service (MMS) published final rules in the Federal Register (Vol. 56, No. 217. November 8. 1991), amending the regulations governing the valuation for royalty purposes of geothermal resources produced from federal leases (56 F.R. 57256). The new rules became effective January 1, 1992. All geothermal resources produced from federal leases on or after that date are to be valued and reported to MMS in accordance with these rules.

A brief description of the rules may be found in the Geothermal Resources Council Bulletin of February 1992. Additional information may be obtained from Mr. Brook at MMS at: (303) 231-3534. 
NORTHERN LIGHTS TO BE POWERED BY GEOTHERMAL ENERGY

OESI Power Corporation anhounced on October 8, 1991, that it signed a letter agreement with the Alaska Energy Authority (AEA) which outlines the initial actions to be taken by the AEA and OESI toward developing \& $12 \mathrm{MWe}$ geothermal power plant project on Unálaska Island in the Aleutian Islands. The letter agreement specifies that OESI will submit a detailed project development plan to the AEA, and the $A E A$ will negotiate and execute agreements for the sale of electricity from the power plant. The AEA will also negotiate certain other agreements and retain a consulting engineer, as well as a geothermal consultant, in order to assist in its review of the project.

The AEA had earlier this year authorized $\$ 60$ million of tax exempt bonds for financing the project, subject to further study. The bonds would finance the cost of the power plant, transmission line, construction support and management, engineering, overhead and construction fees. The tax exempt bond financing is expected to be in place by March 31 . 1992.

Under the terms of the agreement, OESI will construct and then operate the power plant facilities, which will be owned by the AEA. OESI will also develop and provide geothermal fluid from its geothermal resource leasehold. The project is to provide baseload power to the residents of the City of Unalaska, as well as the shipping and fishing industry at the international Port of Dutch Harbor.

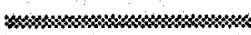

CALIFORNIA

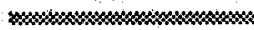

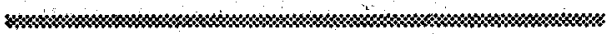

DISTRICT HEATING PURSUED BY MAMMOTH LAKES

The Town of Mammoth Lakes successfully completed a temperature gradient hole at Juniper Ridge on October 1. 1992. Dubbed "Oh Well 1," the hole was drilled to a depth of 2,177 feet by Longyear Drilling Company (Dayton, Nevada). As of September 30, 1991, the bottom hole temperature was $174^{\circ} \mathrm{C}$ $\left(345^{\circ} \mathrm{F}\right)$, which is ideal for use in the district heating system being proposed by the Town. The system, for which Cascadia Exploration Corporation will provide technical expertise, would deliver warm water for space heating of buildings as an alternative to burning fossil fuels or using electricity. Primary funding for the project is provided through a grant from the California Energy Commission.

According to Gene Ciancanelli, consulting geologist, of Cascadia Exploration Corporation, a warm water aquifer was discovered at a depth of 2,035 feet, and formations that appear to contain the suitable geothermal fluids were encountered between 2,035 and 2,055 feet. A fresh water production zone discovered at 670 feet is recommended to 
supplement the Town's limited fresh water production. Because this location is privately owned, federal permitting problems will be avoided.

Ciancanelli says the Town now has two of the three ingredients necessary for success - heat and water. The third ingredient -- permeability of the reservoir -is still unknown. The Town is planning to drill a production well and pump test the aquifer to determine if acceptable quantities of geothermal fluids can be delivered.

While the CEC grant for the next phase of the project has been issued, progress has been stalled because the Town Council was unable to appropriate local matching funds due to severe budget constraints resulting from continuing drought and economic recession. The Town is now seeking private capital to combine with the grant monies, and hopes to raise enough money for a production well, an injection well, a pipeline between the two wells, and a heat exchanger.

For more information contact:

George Fetzer
Project Manager
Town of Mammoth Lakes
P.O. Box 1609
Mammoth Lakes, CA 93546
Phone: (619) $934-8983$
Fax: (619) $934-8608$

Sources: Geothermal Resources Council Bulletin 4/92; George Fetzer, Personal Communication 10/92

\section{CALIFORNIA ENERGY COMMISSION APPOINTS NEW EXECUTIVE DIRECTOR}

B. B. Blevins replaced Stephen $M$. Rhoads as the Executive Director of the California Energy Commission, effective March 2, 1992. In his previous Energy Commission position, Blevins was an advisor to Chairman Charles R. Imbrecht and played a key role in reviewing and recommending energy policies for California. He guided many of the Energy Commission's major policy reports to completion and represented the Chairman in a variety of energy-related forums.

Blevins began working at the Commission as an energy analyst in 1977. From 1981 to 1984 , he served as the project manager for developing California's Energy Shortage Contingency Plan and represented California in a number of oil shortage simulations conducted by the International Energy Agency.

Before coming to the Commission, Blevins was a spokesperson on energy issues for the University of California and an energy researcher at Oak Ridge Associated Universities in Oak Ridge, Tennessee.

Source: Geothermal Resources Council Bulletin 4/92 


\section{GREENHOUSE TO}

\section{GREENHOUSE TO GO COMMERCIAL}

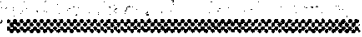

A geothermal greenhouse project located in Lake County, California, has attracted commercial greenhouse developers. The greenhouse is operated by Mendocino - Lake Community College District which offers vocational courses primarily in horticulture and in greentiouse management.

Successful operation of the greenhouse has three commercial operators interested in development, but they are awaiting reservoir test results before investing. The reservoir test will take place once a modification grant agreement to transfer funds originally allocated for greenhouse expansion is approved by CEC.

Expansion of the greenhouse will still occur, but the source of funds will be loans from the CEC. Lake County will repay the loans with revenues from the commercial greenhouses in the form of lease payments.

Source: Geothermal Resources Bulletin $7 / 92$

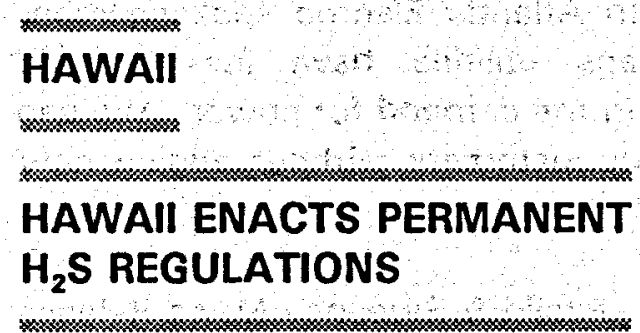

On June 19, 1992, Governor Johń Waihee of the State of Hawaii approved strict new air quality emission standards for $\mathrm{H}_{2} \mathrm{~S}$. The rule sets the statewide standard at 25 parts per billion (ppb) and applies to any industrial release of hydrogen sulfide. The new rule addresses the safety concerns of the community and gives authority to the state health director to impose stricter levels. Although state health officials have said that the $25 \mathrm{ppb}$ standard is 400 times lower than the levels that cause physical effects, such as nose and eye irritations in people, Health Director Dr. Jack Lewin said the limit at geothermal power plants probably would be set at 5 ppb, the odor-detection level in most people. Enactment of the rule clears the way for continued development of geothermal projects for Hawaii County's power-starved electric system.

Source: Geothermal Resources Council Bulletin 6/92

\section{HAWAIIANS SUPPORTING GEOTHERMAL. ENERGY}

On May 13, 1992, in Hilo, Hawaii, more than 5,000 people turned out at the Kanaka'ole Stadium to support the development of geothermal energy on the Big Island. The event was organized by the Hawaii Island Geothermal Alliance, a group of union leaders and business groups in response to the continuing energy crisis, with rolling blackouts which have led to unplanned sewage discharges and water pumping problems, as well as other health and safety threats.

Governor John Waihee addressed the crowd, saying that "Big Islanders understand better than others that dependable power is a necessity for a strong, healthy society." Big Island Mayor Lorraine Inouye agreed. State Senator Richard Matsuura of Hilo spoke of the 
island's geothermal potential, noting its ability not only to power the island, but eventually to help carry abundant Hilo rainfall to parched Kona and South Kona. Lieutenant Governor Ben Cayetano recognized the large percentage of Hawaiians and part-Hawaiians in the audience and said that their participation should be noted because of the assertion by opponents that Hawaiians oppose geothermal energy development.

Steve Morris, project manager of Puna Geothermal Venture, said "the turnout was much greater than expected by the rally planners." Puna's new $25 \mathrm{MW}$ flash/binary power plant, which had been delayed by a technicality concerning air quality standards, came online in October.

Source: Geothermal Resources Council Bulletin 5/92

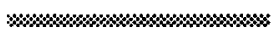

NEW JERSEY

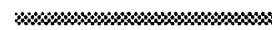

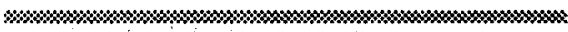

EAST COAST COLLEGE ANNOUNCES GHP PROJECT

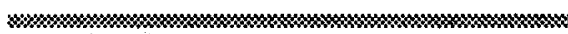

Stockton State College in Pomona, New Jersey, is converting its heating and cooling systems to a geothermal heat pump system. The school will be scrapping its air conditioners, most of its natural gas consumption, and about a quarter of the electricity it uses by going geothermal. The project should be fully operational by September 1993. In southern New Jersey, about 800 homes are already using geothermal energy.

"It will save energy. It will result in fewer pollutants being emitted to the atmosphere. And it will save the college money," said George Klenk, a spokesperson for the New Jersey Department of Environmental Protection and Energy. The Department has approved a $\$ \mathbf{2 . 3 7}$ million grant, about half of what it will cost the school to "geothermalize" the half-million square feet of its sprawling, modern campus in the pinelands of Pomona. Klenk said Stockton would save about $\$ 455,000$ a year on energy bills. Officials at the school have said it could eliminate up to 2,000 tons of carbon dioxide and other pollutants each year.

The 400 wells for the project will be about $\mathbf{4 5 0}$ feet deep where the water is about $13^{\circ} \mathrm{C}\left(55^{\circ} \mathrm{F}\right)$ year-round, and will be connected by a loop of plastic tubing to a heat pump in the basement of a building. When the outside temperature drops below $4.4^{\circ} \mathrm{C}\left(40^{\circ} \mathrm{F}\right)$, electric heat will provide extra warmth, but will require much less electricity than otherwise would be used. In summer, the system will transfer heat from the buildings into the relatively cool ground.

Atlantic Electric, the utility that services Stockton, is giving the college a $\$ 1.1$ million "rebate" to help it pay for the new wells, pumps, and tubes. "We like energy-efficient customers," said Susan Coan, an Atlantic Electric spokesperson. "It means utilities have less-dramatic swings in the demand for power. We can add new customers without adding new plants."

Source: Paolin \& Sweeney News Release 9/10/92 and Geo-Heat Center Monthly Project Progress Report 6-7/92 


\section{TEXAS}

oresesesen

\section{TEXAS HEALTH DEPARTMENT APPROVES RULE CHANGE FOR HEAT PUMP USERS}

On February 22, 1992, the Texas Board of Health for the Texas Public Water Systems adopted new language that allows a heat exchanger in a water-source heat pump system to use potable water for the purpose of heating and air conditioning. Heat pumps using municipal water have been in operation in Pennsylvania, Washington, Oregon, and South Dakota. Some of these installations have been in use for several years, and all have proven to be safe and reliable. $D r$. Wayne $R$. Snodgrass, President-Elect of the American Academy of Clinical Toxicology, reviewed water-source heat pump systems and conducted tests on both ingoing and outcoming water. "Based upon my professional opinion, this heat exchanger does not change the quality of the water or cause contamination of the water ... the individual chemical concentrations of all the chemicals tested are all well below U.S. government federal water quality standards."

In this application, heat is drawn from the water in municipal water systems. A typical configuration consists of a line tapped into the municipal water system either directly off the water main or on the line from the main into a house or business. The water is directed through a heat exchanger and pumped back into the water main through an individual line or a header serving several return lines. Watersource heat pumps make heat pump technology available to structures that have no adjacent space for wells or ground loops. Also, several structures can be served off a single loop fitted with headers. This application will open a new market for heat pumps in areas that previously were not considered economic.

Source: Geothermal Resources Council Bulletin $3 / 92$ 

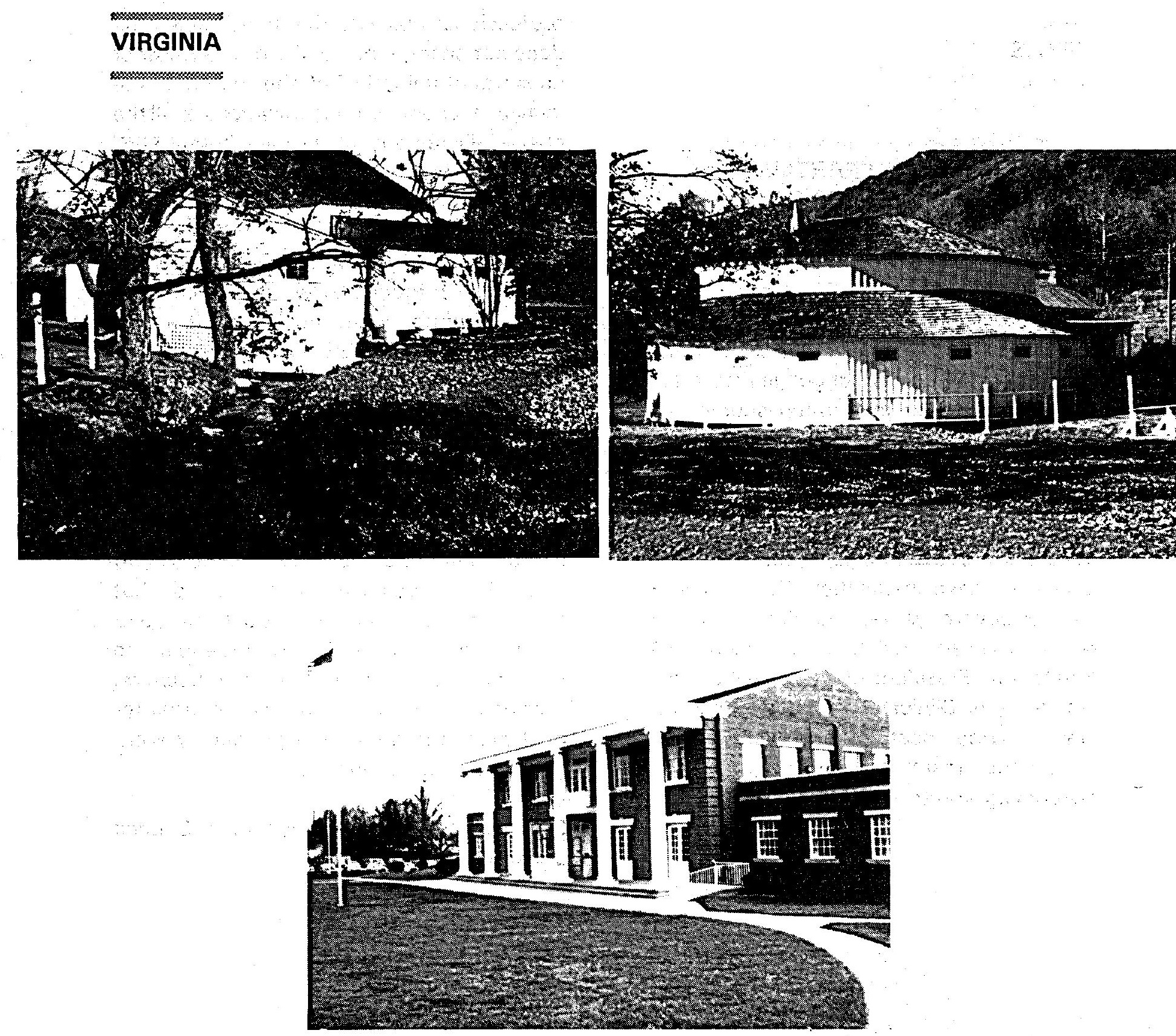

\section{Geothermal Energy in Virginia -- 1761 to 1992}

Because of the purported medicinal benefits of their waters, thermal baths produced by numerous springs in the highlands of Virginia became social gathering places for the rich and famous as early as the 18th century. Top photo at the left shows the men's Warm Springs pool house built in 1761, and believed designed by Thomas Jefferson; the women's pool house built in 1836 is shown at right. Below, modern geothermal use in Virginia is illustrated by the corporate offices of the Northern Virginia Electric Cooperative in Manassas which is heated and cooled by a closed loop geothermal system. (Photos by John Bruce, Rural Living Magazine). 


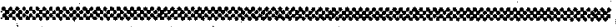

MAJOR GEOTHERMAL POWER DEVELOPMENT PLANNED IN JAPAN, THE PHILIPPINES, INDONESIA, KENYA, AND THE AZORES

Japan

Eight new geothermal power stations under development in Japan will add an additional capacity of $293 \mathrm{MWe}$ to the 270 MWe capacity of the existing nine plants. The new plants include:

- Kakkonda II

- Sumikawa

- Uenotai

- Yanaizu lat Okuaizu in northern Honshu)

- Takigami

- Oguni

- Ogiri (at Kirishima)

- Fushima (in Kyushu)

Size of the individual plants ranges from $25 \mathrm{MWe}$ at Takigami and Oguni to 65 MWe at Yanaizu. Operation dates range from early 1994 to 1996.

\section{Philippines}

The government of the Philippines "now realizes that full development of its geothermal resources is the only alternative to the country's growing electric power requirements," according to a report in IGA News. The recent 15-year Power Development Program of the National Power Corporation calls for an additional power generating capacity of $9,959 \mathrm{MWe}$ by the year 2005 , of which 18 percent is to be filled by geothermal sources. During this interim, the Philippines National Oil Co. (PNOC) will allot 68 percent of its total investments from 1992-1996 into commissioning the following geothermal projects:

- Bacon-Manito I and II in Albay by 1993

- Palimpinon II by 1993

- Mt. Apo I and II in 1995

- Bulusan, Cagua, and Del Gallego in Luzon by 1995

- Leyte A in 1997.

In addition, binary cycle units will be introduced to utilize the heat of waste brines, first at the 330 MWe MakilingBanahaw plant in Laguna, and later at the 15-20 MWe Maibarara project in Laguna, nearly doubling its capacity.

Currently, the Philippines' aggregate geothermal capacity is 888 MWe, and generation is close to $4.9 \mathrm{GWh}$ annually. This displaces 8.3 million barrels of fuel oil and retains $\$ 142$ million (U.S.) within the Philippine economy which would otherwise be spent for oil imports.

Important decisions by the Philippine Supreme Court and the National Economic 
and Development Authority (NEDA) recently allowed PNOC and the National Power Corporation (NAPOCOR) to proceed with construction and operation of the Mt. Apo geothermal power plants in North Cotabato, Mindanao. According to IGA News, the high court ruling virtually paved the way for the Department of Environment and Natural Resources (DENR) to issue an environmental compliance certificate to this NAPOCOR project. The project is geared toward alleviating the worsening power crisis on Mindanao and is expected to add 120 MWe to the hydroelectric-dependent Mindanao grid, which suffers from power supply curtailment due to severe drought.

This project will cover some 1,112 acres of the 111,195 acre National Park, specifically in the thermal areas of Kidapawan, North Cotabato. It will cost about US $\$ 300$ million and will involve the drilling of production wells and installation of steam-gathering systems by PNOC and the construction of six units of $20 \mathrm{MWe}$ baseload power generators and the associated transmission power line by NAPOCOR.

PNOC and NAPOCOR are committed to provide an environmental and tribal welfare trust fund for the Mt. Apo project and will each contribute to the trust fund at the rate of US 0.04 cents per kWh based on net sales of generated power. The two government agencies also pledged to join a multi-sectoral group to manage this geothermal site. The group will be headed by DENR with representatives from PNOC. NAPOCOR, local governments, tribal consultative council, non-governmental organizations, and the religious sector. PNOC and NAPOCOR will arrange loans or grants for the group's projects and will also be tasked with ensuring that the money released from the trust fund will be used for the conservation and development of the Mt. Apo watershed, livelihood projects for the upland communities in the area, and protection of the Mt. Apo National Park ancestral domain. The creation of the multi-sector management group and the trust fund, as well as the latter's funding by the PNOC and NAPOCOR, were major conditions set by the DENR in issuing the environmental compliance certificate for the project.

\section{Indonesia}

Indonesia is similarly developing an energy policy that reduces its dependence on fuel oil as a source of primary energy. The government intends to increase the installed geothermal electrical capacity from 142.5 MWe at present to $430 \mathrm{MWe}$ by 1995 , and $870 \mathrm{MWe}$ by the year 2000 .

Indonesia's geothermal program has been gaining momentum in the last few years with the successful operation of Units 1, 2, and 3 at Kamojang (140 MWe) and the planned developments at Darajat (55 MWe), Dieng (55 MWe), Salak (110 MWe), and Lahendong (20 MWe). Many new areas have been investigated and preliminary drilling carried out to test scientific conceptual models and system productivities. Small-scale geothermal developments $1<10 \mathrm{MWe}$, early recognized as having potential in the rural and more remote parts of the country, have maintained a prospective role in Indonesian overall energy planning, with the ongoing investigations in Lahendong in 
Sulawesi, Kerinci in Sumatra, and Ulumbu in Flores.

\section{Kenya}

Two additional $32 \mathrm{MWe}$ geothermal generating units are scheduled for operation in 1994 and 1995 at the Greater Olkaria Geothermal Field in Kenya. A total of 27 wells have been drilled in the northeast part of the field to serve the new units. Nineteen of the 27 wells had been tested by early 1992 and produced about $56 \mathrm{MWe}$ of the required $64 \mathrm{MWe}$; the eight wells remaining to be tested were expected to provide at least $16 \mathrm{MWe}$. Plans are to drill four make-up wells for the existing 45 MWe plant in the eastern part of the field, four reserve wells in the northeast, and two exploratory wells in the next development area to the west.

Exploration at another field, Eburru about $\mathbf{3 7}$ miles north of Olkaria indicates that it could be of commercial value only with binary technology. Leasing of the small field to a private developer is under consideration if favorable bids can be secured.

\section{Azores}

Further geothermal exploration in Săo Miguel has been announced by the Sociedade Geotermica dos Açores (SOGEO). The overall target is to develop geothermal power generation to supply 60 percent of the island's electricity needs. The European Commission is to meet 35 percent of the costs of the exploration phase.
Source: IGA News $10-12 / 91 ; 1-3$ and 4$6 / 92$

Plans to generate electricity from Canada's geothermal resource at Meager Creek, located about 100 miles north of Vancouver, British Columbia, moved forward with the establishment of the Meager Creek Joint Venture. Under the terms of the agreement, Guy F. Atkinson Holdings Ltd., or its affiliates, owns 57 percent of the joint venture in exchange for funding the initial development phase of the project. The remaining 43 percent is held by Canadian Crew Energy Corporation. Commonwealth Construction Company, a division of Guy F. Atkinson Holdings, Ltd., will be the project manager and operator for the project. The Joint Venture proposes to develop Canada's first geothermal power plant at an estimated capital cost of approximately $\$ 170$ million by late 1995 with an initial capacity of 60 $M W$. The Meager Creek resource has been estimated to have a potential of $260 \mathrm{MW}$.

The original discovery of the Meager Mountain geothermal resource was made by B.C. Hydro and Power Authority and Canada's Department of Energy, Mines and Resources in the course of a major energy exploration campaign in the 1970 s and early 1980s. Jointly and separately, they ran 60 miles of geophysical survey lines and drilled 10 test wells. Activities previously had been terminated in the mid- 
1980s when fuel prices and electric load growth dropped.

The activities in the initial development phase of the joint venture include the permitting and regulatory process, initiation of the applicable public consultation and environmental programs, finalization of a detailed reservoir confirmation program, preparation of a detailed drilling program, and negotiation of the terms of a power sales contract with B.C. Hydro. A field program will also be pursued to confirm the commercial viability of the project. The field program will include a confirmation drilling phase in preparation for the engineering, design, and construction of the geothermal power plant. To date, some $\$ 35$ million has been spent developing the Meager Creek project to its present stage.

As a result of a public sale held in late 1991, the British Columbia Ministry of Energy, Mines and Petroleum Resources, has awarded a geothermal permit on Parcel 41662, the Pebble Creek Prospect, to Andrew E. Nevin \& Associates of San Francisco, California. The parcel, which is on the north slope of Mount Meager, is near B.C. Hydro and Power Authority's 230- and 400-kV power line corridor through Pemberton, B.C. The permit conveys the right to explore for and develop the prospect's geothermal resources, subject to provisions of the Geothermal Resources Act and specific conditions required by the Ministry.
The project plan is to drill wells, produce the natural steam, and convert it to electric power, using several $10 \mathrm{MW}$ modular, condensing, turbine generators until the capacity of the geothermal field is reached. The capacity of the resource is not yet known. Power will be marketed to utilities in British Columbia, or to the high load-growth markets in Washington and Oregon.

Source: Geothermal Resources Council Bulletin 2/92; Canadian Crew Energy Corporation News Releases 12/9/91. 7/30/92

\section{NEW DIRECT USE PLANS ANNOUNCED IN HOLLAND AND ITALY}

The Dutch government has recently announced various initiatives to reduce the use of natural gas for home heating to limit emissions. A target of 150,000 homes using both deep, low-enthalpy geothermal and ground-source geothermal heat pumps has been set for the year 2000 .

In Italy, the City Council of Ferrara (to the northeast of Bologna) plans to link 300 buildings, more than 20 percent of the city's housing, to a centralized geothermal district heating unit using fluids at $90-95^{\circ} \mathrm{C}$ $\left(194-203^{\circ} \mathrm{F}\right)$. The system is to be run by the municipal utilities.

Source: IGA News 4-6/92 
A scientific prototype of a commercial HDR system is planned for 1994 under the auspices of the European Communities. The Project will be carried out by a consortium of European companies called "European HDR Industries." Different locations are presently being evaluated for site suitability. Candidate sites for the HDR system included Cornwall/England, Urach/Germany, and Soutlz-sousForets/France. The major scientific and drilling activities at these three sites are already being managed as one European program by a multinational association consisting of industries and major scientific organizations.

At Soultz, a 16,896-foot deep well (called GPK-1) was drilled during Phase $I$ in 1987-89 and reached crystalline basement at a 400 foot depth. Bottom-hole temperature at 16,896 feet is $140.3^{\circ} \mathrm{C}$ $\left(285^{\circ} \mathrm{F}\right)$. The natural stress and the network of joints are typical for a young graben and favor the stimulation of an extended system of surface areas for heat exchange in the granite. Recent large-scale stimulation tests have demonstrated the capacity of significant enhancement of permeability of the joint network at the 610-foot level.

During $1990 / 91$ an additional exploration core drill (called EPS-1) was drilled to 679 feet, where the temperature reached was $148^{\circ} \mathrm{C}\left(300^{\circ} \mathrm{F}\right)$. Phase II at the Soultz site, a feasibility study for the design of an HDR system, is presently in preparation.

Source: IGA News 1-3/92

\section{DEVELOPMENT INITIATED IN BERLIN GEOTHERMAL FIELD IN EL SALVADOR}

Two wellhead units of $5 \mathrm{MWe}$ each have been installed in the Berlin geothermal field, located in the eastern part of El Salvador. The first unit began operation on February 20, 1992; the second unit will begin operation as soon as permanent injection facilities are available. The generating and injection equipment and its financing have been provided through a commercial loan to the El Salvadoran Government by the Belgian Government and industry.

The Berlin geothermal field was first evaluated in the 1960 s by a United Nations exploration project in cooperation with the Government of El Salvador. In the 1970s, the World Bank supported five deep wells all of which encountered high-enthalpy geothermal fluids with temperatures of $280^{\circ}-300^{\circ} \mathrm{C} \quad\left(536^{\circ}-572^{\circ} \mathrm{F}\right)$ Total production capacity of four of these deep wells is at least 25 MWe.

In 1982, a feasibility study for the installation of a $55 \mathrm{MWe}$ generating unit was carried out. The Government of EI Salvador, however, believes that reservoir modelling at Berlin needs to be refined on the basis of additional data, and detailed geoscientific investigations and the drilling of a sufficient number of deep wells are 
necessary. A new program with the financial support from the World Bank and the Inter-American Development Bank is being implemented.

The Government of El Salvador considers the area of Berlin of great strategic importance. The development of its geothermal resources would contribute to the rapid economic growth of the eastern part of the country, with a consequent consolidation of the recently achieved political stability.

Source: IGA News 1-3/92
The Neuquén Provincial Energy Agency (Ente Provincial de Energía del Neuquén EPEN) is in charge of developing geothermal energy in the Province of Neuguen in Argentina. The agency has expressed its willingness to enter into agreements with national or foreign private enterprises that wish to participate in the development of geothermal energy resources, either as a partner of EPEN or as an investor.

The most significant geothermal resources in the province are located in Copahue and Domuyo. Copahue is a geothermal field located 563 miles from the province's capital, Neuguén; it is character- -ized by a steam-dominated reservoir with $a$ depth between 2,400 and 4,590 feet. Three producing wells have been drilled, one of which is being used to operate a binary-cycle pilot plant of $670 \mathrm{kWe}$. EPEN and the Japan International Cooperation Agency (JICA) have completed the reservoir engineering, technical and economic feasibility studies needed for the installation of a commercial geothermal plant. In view of the high cost of any other current alternative, a district heating system using geothermal fluids from Copahue is also being planned. Domuyo is a geothermal area located in the northern part of the province. A prefeasibility study has been completed, suggesting the existence of a geothermal field at a depth between 1,968 and 3,280 feet, with temperatures of approximately $230^{\circ} \mathrm{C}$ $\left(446^{\circ} \mathrm{F}\right)$. Private developers may be able to participate in the development of this geothermal area, sharing the exploration risks and the technical and economic feasibility study.

For further information, contact:

Mr. José Luis Sierra
Dirección de Nuevas Fuentes
de Energía
Ente Provincial de Energía del
$\quad$ Neuquén (EPEN)
Belgrado $255-(8300)$ Neuguén -
ARGENTINA
Fax: $(0943) 34572$
Telex: 84279 EPEN AR

Source: IGA News 1-3/92 


\section{DOE GEOTHERMAL DIVISION HOLDS GEOTHERMAL PROGRAM REVIEW $X$}

Each year the Geothermal Division of the U.S. Department of Energy conducts an in-depth review of its entire geothermal $R \& D$ program. The conference serves as: a status report on current $R \& D$ activities, an assessment of progress and problems, a review of management issues, and a technology transfer opportunity between DOE and the U.S. geothermal community.

Program Review $X$, the tenth of the series, was held in San Francisco on March 24-26, 1992. The theme of the review, "Geothermal Energy and the Utility Market - The Opportunities and Challenges for Expanding Geothermal Energy in a Competitive Supply Market," focused on the needs of the electric utility sector.

Program Review $X$ consisted of seven sessions including an opening session with presentations by Mr. Vikram Budhraja, Vice President of System Planning and Operations, Southern California Edison Company, and Mr. Richard Jaros, President and Chief Operating Officer, California Energy Company. (See DEVELOPMENT STATUS.) Six technical sessions included presentations by researchers covering DOEsponsored $R \& D$ in hydrothermal, hot dry rock, and geopressured energy.

As with previous program reviews, a key facet of Program Review $X$ was an "Industry Critique" session organized and chaired by the National Geothermal Association (NGA). Five NGA representatives were invited to comment on specific areas of DOE's geothermal R\&D: Exploration, Reservoir Engineering, Drilling, Production, and Power Generation. Their comments provided valuable insight into near-term industry concerns and needs and reinforced the basic thrust of the DOE program.

\section{GOVERNMENT/INDUSTRY PROMOTE USE OF GEOTHERMAL HEAT PUMPS}

On July 21, 1992, the first of three teleconferences was broadcast nationwide on the use of geothermal heat pumps, with an estimated 3,500 listeners. Each of the teleconferences will target a different audience and therefore have a slightly different agenda. The first focused on utilities with the remaining two targeted for dealers/contractors and architects/ engineers on March 3 and April 28, 1993, respectively.

The first teleconference included supporting statements from government officials and utility executives, examples of successful applications and case studies, and a panel discussion by utility representatives and regulators.

The project is being implemented by the International Ground Source Heat Pump Association at Oklahoma State University. For the first teleconference, the two uplink sites were located in Washington, D.C., and Oklahoma City, Oklahoma, and hundreds of downlink sites were located across the country. Hosts and locations for downsites for the remaining teleconferences are currently being 
coordinated. The teleconferences are being funded by several of the sponsors which include DOE's Office of Utility Technologies, DOE Dallas Support Office, Environmental Protection Agency, International Ground Source Heat Pump Association, Electric Power Research Institute, National Rural Electric Cooperative Association, Edison Electric Institute, Earth Energy Association, Public Service Company of Indiana, and the State of Missouri. Preliminary informational brochures may be obtained from Policy Research Associates, Inc., Attn: Debra J. Brown, 11260 Roger Bacon Drive, Suite 206, Reston, VA 22090.

\section{MONOGRAPH ON THE GEYSERS GEOTHERMAL FIELD}

The Geothermal Resources Council has announced the publication of Special Report No. 17. Monograph on the Geysers Geothermal Field. The 327-page volume contains 34 papers by 49 authors. The publication was edited by Claudia Stone and was financially supported by DOE's Division of Geothermal Energy.

The monograph represents a broad and well balanced sampling of the latest theory and technology developed for The Geysers. The papers are grouped into three sections: Geothermal Resources, Geothermal Technology, and a Case Study of Unit 18. The geothermal resources section includes a description of the historical setting and development, including a photo album, discussion of geology and geothermal phenomena, and a description of the reservoir based on integrated analyses of geological, geophysical, geochemical, and reservoir engineering data. The Geothermal Technology section describes drilling, steam production, fluid handling, electric power generation, and environmental issues. The Case Study of Unit 18 traces the development of that part of the steam field and the design, construction, and operation of the 119 MWe PG\&E plant.

Cooperative efforts of the principal developers are illustrated by the large amount of proprietary data released specifically for this publication. Two maps showing the top of the steam reservoir and the top of the intrusive felsite are included in a pocket, along with a 1:20,000 map of The Geysers Geothermal Field.

Monograph on the Geysers Geothermal Field IGRC Special Report No. 17 is available from the Geothermal Resources Council, P.O. Box 1350, Davis, CA 95617-1350, USA. Fax: (916) 758-2839. The cost is US $\$ 28.501+$ US $\$ 5.00$ for shipping outside the United States).

Source: IGA News 4-6/92
(Excerpted from an article "Geothermal Standards....A Decade of Leadership Continues". in the GRC Bulletin of $12 / 91$ by John Rowley, Pajarito Enterprises, 3 Jemez Lane, Los Alamos, New 
Mexico 87544, Phone: (505) 672 9770)

Building on over a decade of experience in development and maintenance of geothermal-related technology standards, the current Technical Standards Committee of the GRC Board of Directors, of which Dr. Rowley is chairman, has been charged to rejuvenate the involvement of the geothermal industry in the development of appropriate standards. The current trend toward the consolidation of markets, as evidenced in the European community, and concern for international markets provide a major impetus for this action.

The geothermal community's involvement in technical standards stems from the formation of the Committee on Standards for Geothermal Resources and Energy as Committee E45 of the American Society of Testing and Materials in 1979. The E45 group rapidly expanded with the addition of technical subcommittees on drilling, logging, field development, energy utilization systems, sampling and chemical analysis, product recovery, geothermal heat pump applications, emission abatement and waste disposal, and materials. Representatives of producers, users, consumers, and general interest groups participated, with GRC playing a central role. The standards approved by this group are shown below. Their use is completely voluntary. 
List of Geothermal ASTM Standards

A. Standards in Print (ASTM, 1989)

\begin{tabular}{|c|c|c|}
\hline $\begin{array}{l}\text { ASTM ID } \\
\text { Number }\end{array}$ & Title & Status/Comment \\
\hline E 1128-86 & $\begin{array}{l}\text { Establishing Parameters For } \\
\text { Testing Dynamic Seals for } \\
\text { Geothermal Use }\end{array}$ & $\begin{array}{l}\text { Request for update and } \\
\text { revision }\end{array}$ \\
\hline$E 0947-83$ & $\begin{array}{l}\text { Sampling Single-Phase } \\
\text { Geothermal Liquid or Steam } \\
\text { for Purposes of Chemical } \\
\text { Analysis }\end{array}$ & Active \\
\hline E 1008-84 & $\begin{array}{l}\text { Installation, Inspection, and } \\
\text { Maintenance of Valve Body } \\
\text { Pressure Relief Methods for } \\
\text { Geothermal and Other } \\
\text { High-Temperature Liquid } \\
\text { Applications }\end{array}$ & Active \\
\hline E 0974-83 & $\begin{array}{l}\text { Specifying Thermal } \\
\text { Performance of Geothermal } \\
\text { Power Systems }\end{array}$ & Active \\
\hline E $1068-85$ & $\begin{array}{l}\text { Testing Non-metallic Seal } \\
\text { Materials by Immersion in a } \\
\text { Simulated Geothermal Test } \\
\text { Fluid }\end{array}$ & Active \\
\hline E $1069-85$ & $\begin{array}{l}\text { Testing Polymeric Seal } \\
\text { Materials for Geothermal } \\
\text { and/or High-Temperature } \\
\text { Service Under Sealing } \\
\text { Stress }\end{array}$ & Active \\
\hline E 0957-84 & $\begin{array}{l}\text { Geothermal Energy, } \\
\text { Definition of Terms } \\
\text { (including Heat Pumps) }\end{array}$ & Active \\
\hline
\end{tabular}

By 1988, in face of decreased funding for alternative energy projects, the geothermal group was melded into the present Committee on Solar, Geothermal, and Other Alternative Energy Sources (E44). The current geothermal standards subcommittees and proposed chairmen are as follows: 
Current Geothermal Standards

Subcommittees, ASTM E $\mathbf{4 4}$ Committee

\begin{tabular}{|c|l|l|}
\hline ASTM ID & \multicolumn{1}{|c|}{ Subcommittee Title } & \multicolumn{1}{|c|}{ Contact } \\
\hline \hline E44-1500 & Field Development & $\begin{array}{l}\text { Steve Pye, Unocal, } \\
\text { (213) 977-6262 }\end{array}$ \\
\hline E44-1501 & $\begin{array}{l}\text { Sampling and Chemical } \\
\text { Analysis }\end{array}$ & $\begin{array}{l}\text { Don Christofferson, } \\
\text { Unocal, (415) 528-7201 }\end{array}$ \\
\hline E44-1503 & Drilling & $\begin{array}{l}\text { Bill Godare, Foster Valve, } \\
\text { (713) 690-3553 }\end{array}$ \\
\hline E44-2000 & Utilization & $\begin{array}{l}\text { Gordon Bloomquist, WA } \\
\text { State Energy Office, } \\
\text { (206) 586-5074 }\end{array}$ \\
\hline E44-4000 & Materials & $\begin{array}{l}\text { Dave Anderson, GRC, } \\
\text { (916) 758-2360 }\end{array}$ \\
\hline
\end{tabular}

In addition to an indication of emerging needs for standards in a number of areas of activities -- e.g., drilling, scale control, waste handling, tankage, and sampling of two-phase flows -- the renewed interest within GRC is motivated by the concerns of potential geothermal exporters that international trade reciprocities will not be put in place without accepted certifications and standards. To paraphrase J. C. $O^{\prime}$ Grady, writing in the October 1989 issue of Export Today: "Where this reciprocity is lacking. American refrigerators and baseball bats [and geothermal export items] sit on foreign docks, devoid of magic local approval, soaking up sunshine and billions of dollars."

Anyone wishing to serve on any of the geothermal subcommittees of E44 or to suggest new standards may contact any of the subcommittee chairmen or John Rowley, current first vice chairman of the committee, at (505) 672-9770.

\section{INTERNATIONAL SYMPOSIUM ON GEOTHERMAL ENERGY TO BE HELD IN ST. PETERSBURG, RUSSIA}

An International Symposium entitled Problems in Geothermal Energy has been announced for June 21-27, 1993, in St. Petersburg, Russia. The sponsors, the Leningrad Mining Institute and Soviet Geothermal Association expect that the wide range of issues to be discussed will permit participants to gain a greater understanding of geothermal energy resources evaluation, operations, and utilization. 
Details of the symposium are found in the GRC Bulletin of December 1991. For more information, please contact the Foreign Co-Chairman of the Program Committee:

Prof. Paul Kruger

Civil Engineering Dept.

Stanford University

Stanford, CA 94305

Telephone: (415) 725-2099

Fax: $(415)$ 725-8662

\section{INTERNATIONAL CONFERENCE ON INDUSTRIAL USES OF GEOTHERMAL ENERGY}

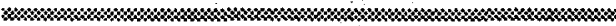

Sponsored by the Federation of Icelandic Industries and others, an International Conference on Industrial Uses of Geothermal Energy was held in Reykjavik, Iceland, in September 1992. Over 180 participants from 31 countries represented government agencies ranging from the local to international level, private industry, and the academic community.

Three plenary sessions addressed, respectively, an Overview of Industrial Applications, Research and Development Aspects of Industrial Utilization, and Diverse Issues Related to Industrial Applications. Technical sessions addressed the technical characteristics of geothermal fluids, field management, environmental and economic aspects of geothermal utilization, factors affecting the siting of industrial uses, and future prospects. Other technical sessions were more oriented to specific process applications and country-by-country reviews of industrial uses.

DOE was represented in the first plenary session by Dr. John E. Mock, Director, Geothermal Division, discussing the Department's support for growth in the industrial use of geothermal energy. Other U.S. speakers and their paper topics included F. C. Monastero of the Naval Air Weapons Station on "The Tectonic Influence on Geothermal Resources in the Southwestern Basin and Range of the U.S.": E. T. Premuzic of the Brookhaven National Laboratory on "Developments in Geothermal Waste Treatment Biotechnology"; W.P.C. Duyvesteyn of BHP -Utah International, Inc. Minerals Laboratory on "Recovery of Base Metals from Geothermal Brines"; and Jane Negusde Wys of EG\&G Idaho on "The Geopressured Habitat and Potential Uses of the Geopressured Resource."

In addition to several governmental, utility, and academic co-sponsors from Iceland, the conference was also supported by the International Geothermal Association and the Commission of the European Communities - DGXII.

\section{AGREEMENT TO OPERATE UNU IN ICELAND EXTENDED TO 1996}

The agreement between the United Nations University Geothermal Training Program and Orkustofnun, the National Energy Authority of Iceland, has been extended to 1996. The aim of this program is to assist developing countries with significant geothermal potential to 
build groups of specialists who are versed in most aspects of geothermal exploration and development. Priority is given to candidates from institutions where these activities are already underway. Participants from developing countries receive all-inclusive scholarships which are financed by the government of Iceland and UNU, and in some cases by the United Nations Development Fund. The total cost of training per student is about $\$ 30,000$. Qualified participants from industrialized countries can be accepted on the condition that they have scholarships from their country. Further information may be obtained from:

\section{UNU Geothermal Training Programme Orkustofnun \\ Grensasvegi 9 108 Reykjavik, Iceland}

During 1979-1991, 106 scientists and engineers from 22 countries completed the six-month course. Of these, 44 percent came from Asia, 32 percent from Africa, 14 percent from Latin America, and 11 percent from East Europe. All participants have B.S. degrees in science or engineering, many hold master's degrees, and several have Ph.D. degrees when they come for training.

Source: IGA News 10-12/91

\section{GEOTHERMAL INSTITUTE PLANS EXPANSION}

The Geothermal Institute at the University of Auckland (New Zealand) has trained 379 earth scientists and engineers in geothermal technology since 1979. Initiated by the United Nations Development Program and the New Zealand Ministry of Foreign Affairs, the Institute is now sponsored by the New Zealand Ministry of External Relations and Trade. Up to 30 students a year, a majority from developing countries (see Table), have enrolled in the Institute's intensive 9-month course for a Diploma in Geothermal Energy Technology. A 3month course, Geothermal Reservoir Engineering, has been offered since 1988. Beginning in 1993, another 3-month course, Environmental and Hazards Assessment of Geothermal Prospects, will be offered. Three additional short courses are in the planning stages, Low Temperature Utilization, Design of Surface Equipment for Steamfields, and Geothermal Reservoir Assessment. 


\section{Geothermal Diploma Students}

\begin{tabular}{|c|c|c|c|c|c|c|c|c|c|c|c|c|c|c|c|}
\hline COUNTRY & 79 & 80 & 81 & 82 & 83 & 84 & 85 & 86 & 87 & 88 & 89 & 90 & 91 & 92 & Tot \\
\hline Indonesia & 7 & 2 & 5 & 4 & 7 & 6 & 8 & 10 & 6 & 8 & 6 & 6 & 4 & 4 & 83 \\
\hline Philippines & 2 & 5 & 4 & 4 & 5 & 4 & 6 & 50 & 5 & 6 & 4. & 6 & 6 & 5 & 67 \\
\hline Chine & 2 & 4 & 3 & 1 & 1 & 2 & 1 & 2 & 4 & 4 & 3 & 4 & 3 & 2 & 36 \\
\hline New Zealand & 4 & 7 & 3 & 4. & 5 & 3 & 3 & 1 & $\therefore$ & 1 & 1 & - & 1 & 1 & 34 \\
\hline Ethiopia & 1 & 2 & 2 & 3 & 4 & 5 & 2 & 1 & 1. & 1 & 1 & 2 & - & $\therefore$ & 24 \\
\hline Kenya & 3 & $\therefore$ & 1 & 2 & 1 & $\because$ & 1 & 1 & 1 & 2 & 2 & 1 & 2 & 2 & 19 \\
\hline El Salvador & $\therefore$ & 1 & - & 1 & 1 & 2 & 2 & 1 & 1 & 1 & 1 & 2 & 2 & 2 & 17 \\
\hline Thailand & - & $\therefore$ & - & 1 & 2 & 1 & 2 & 1 & 2 & 1 & 3 & 1 & - & 1 & 15 \\
\hline India & 1 & 2 & 2 & 1 & 1 & $\cdot$ & $\cdot$ & - & 1 & 1 & 1 & - & - & - & 10 \\
\hline Mexico & - & 2 & 1 & 1 & - & - & 1 & 1 & 1 & - & 1 & 1 & - & - & 9 \\
\hline Turkey & 1 & $\therefore$ & 2 & - & 1 & $\because$ & 1 & 1 & 2 & - & 1 & - & - & - & 9 \\
\hline Tanzania & - & 2 & 1 & 1 & 1 & 1 & - & $\therefore$ & - & - & $=$ & - & 1 & 1 & 8 \\
\hline Nicaragua & 1 & - & - & 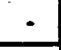 & $\cdot$ & $\cdot$ & - & - & $\cdot$ & - & 2 & 1 & 1 & 1 & 6 \\
\hline Colombia & - & - & 2 & 1 & 1 & 1 & $\cdot$ & $\therefore$ & - & - & $\therefore$ & $\therefore$ & - & - & 5 \\
\hline Dijibouti & $\therefore$ & $\therefore$ & $\therefore$ & $\cdot$ & $\because$ & 1 & 1 & 1 & - & 1 & - & 1 & - & $\therefore$ & 5 \\
\hline Panama & $\because$ & - & $\cdot$ & $\therefore$ & - & - & 1 & 1 & 1 & 1 & - & - & - & 1 & 5 \\
\hline Argentina & - & - & - & - & - & - & - & - & 1 & 1 & - & 1 & 1 & $\therefore$ & 4 \\
\hline Costa Rica & - & - & $\cdot$ & $\bullet$ & - & - & $\cdot$ & $\cdot$ & 1 & - & - & - & 1 & 1 & 3 \\
\hline Ecuador & - & $\therefore$ & 1 & $\therefore$ & $=$ & - & - & - & 1 & 1 & - & $\cdots$ & - & - & 3 \\
\hline Romania & - & 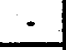 & $\cdot$ & $\cdot$ & $\cdot$ & 1 & - & $\therefore$ & $\bullet$ & - & - & - & 1 & 1 & 3 \\
\hline Bolivie & $\therefore$ & - & - & $\therefore$ & $\therefore$ & 1 & - & 1 & $\cdot$ & - & - & - & $\because$ & $\bullet$ & 2 \\
\hline Chile & 2 & $\therefore$ & - & $\cdot$ & . & - & $\cdot$ & $\therefore$ & - & - & $\therefore$ & $\cdots$ & - & $\cdot$ & 2 \\
\hline Peru & - & $\dot{-}$ & - & $\because$ & $\therefore$ & $\therefore$ & $\dot{-}$ & $\cdot$ & $\therefore$ & - & $\therefore$ & 1 & 1 & $\therefore$ & 2 \\
\hline Vietnam & - & - & $\cdot$ & $\therefore$ & 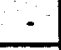 & $\therefore$ & $\cdot$ & $\cdot$ & $\cdot$ & - & 2 & - & $\because$ & $\cdot$ & 2 \\
\hline Dominican Rep. & - & - & - & $\cdot$ & 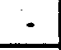 & $\dot{-}$ & - & - & $\cdot$ & $\therefore$ & - & $\therefore$ & - & 1 & 1 \\
\hline Egypt & - & - & - & - & - & - & - & - & - & $\therefore$ & - & 1 & - & - & 1 \\
\hline Guatemala & $\cdot$ & $\cdot$ & $\cdot$ & - & - & $\cdot$ & $\cdot$ & - & - & $\therefore$ & - & 1 & - & - & 1 \\
\hline Japan & - & $\cdot$ & - & - & - & - & 1 & $\cdot$ & - & - & - & $=$ & $\therefore$ & $\therefore$ & 1 \\
\hline Nigeria & - & - & - & - & - & - & $\cdot$ & $\dot{-}$ & - & - & 1 & $\because$ & $\because$ & $\therefore$ & 1 \\
\hline Papua N.G. & - & - & - & - & - & - & - & - & - & - & - & 1 & - & - & 1 \\
\hline Earth Scientists & 11 & 12 & 16 & 14 & 17 & 19 & 13 & 12 & 14 & 15 & 14 & 19 & 12 & 10 & 198 \\
\hline Engineers & 13 & 14 & 11 & 10 & 13 & 9 & 17 & 15 & 14 & 14 & 15 & 11 & 12 & 13 & 181 \\
\hline Total & 24 & 26 & 27 & 24 & 30 & 28 & 30 & 27 & 28 & 29 & 29 & 30 & 24 & 23 & 379 \\
\hline 6 wks training & - & - & - & 3 & - & 8 & 5 & 2 & 6 & 6 & 3 & 4 & 2 & - & 39 \\
\hline
\end{tabular}

Source: Geothermal Resources Bulletin 6/92 


\section{GEOTHERMAL GRADUATE PROGRAM ANNOUNCED FOR MEXICO IN 1993}

A geothermal graduate program will be offered from February 8 to December 23. 1993, by the Universidad Autónoma de Baja California, in collaboration with the Comision Federal de Electricidad (CFE), the Instituto de Investigaciónes Eléctricas (IIE), and the Consejo Nacional de Ciencia $y$ Technologia (CONACYT). The main objective of the program is to prepare professionals capable of applying techniques and methodologies in exploration, drilling and geothermal exploitation for the scientific and efficient utilization of geothermal reservoirs, either producing electric power or used directly.

The candidates must hold a Bachelor's degree in science or engineering or an equivalent level of attainment. Adequate technical English language reading and work experience in geothermal is recommended.

The Program is organized into an introductory seminar of two weeks, two periods of 16 weeks of lectures and practical experience, and two periods of two-weeks evaluation. The practical experience is carried out at the Cerro Prieto geothermal field, which is $\mathbf{3 0}$ minutes away from the University. Additional field trips are conducted to the Imperial Valley geothermal plants in California, United States.

To date, 46 students have attended the annual geothermal course in Mexicali,
México, and 7 students are enrolled in the present course.

For further information, contact:

The Coordinator of the Geothermal Graduate Program

Instituto de Ingenieria

Universidad Autónoma de Baja Califórnia

Boulevard Benito Juarez y Calle de la Normal s/n

Mexicali, Baja California, México

Source: IGA News 4-6/92

\section{WORKSHOP ON ENVIRONMENTAL IMPACT, NATURAL RISKS, AND REINJECTION IN LATIN AMERICAN GEOTHERMAL AREAS}

The Latin American Energy Organization (OLADE) and the United Nations Department of Technical Cooperation for Development (UNDTCD) are implementing a regional project on the assessment of the environmental impact, natural risks, and reinjection in geothermal areas, which began with a workshop held in Quito, Ecuador, on November 25-27, 1991, attended by technical experts and decision makers of the institutions involved in geothermal activities from nine Latin American countries (Argentina, Bolivia, Columbia, Costa Rica, Ecuador, El Salvador, Guatemala, Mexico, and Nicaragua).

The Workshop's objectives were to learn about the current status of geothermal energy and the development of 
geothermal programs in the countries represented in the workshop; the criteria used to assess their environmental impact and the measures applied to minimize it; experiences in the disposal of geothermal brines and gases, especially with respect to reinjection; studies conducted on natural risks in geothermal projects; and the requirements for training, technical assistance, and intra-regional cooperation.

On the basis of information obtained from this workshop, the OLADE-UNDTCD Project will implement three case studies over the next two years: one on environmental impact, the second on natural risks, and the third on reinjection.

Source: IGA News 10-12/91

\section{GEOTHERMAL GUIDES FOR LATIN AMERICAN DEVELOP- MENT IN PREPARATION}

Pursuant to a technical cooperation agreement between the Inter-American Development Bank (IDB) and OLADE, the preparation of six guides for geothermal exploration and exploitation began in January 1992, with the participation of 14 international consultants and Latin American experts with wide-ranging experience in various fields of geothermal expertise.

This Project is aimed at updating and complementing the methodologies that OLADE prepared between 1978 and 1986. These methodologies should guide the region's countries in their efforts to implement studies by specifying activities that must be carried out in phases of reconnaissance, prefeasibility, and exploration of feasibility; in the assessment of the energy potential of geothermal areas; in the preparation of investment projects in geothermal plants and direct use; and in the operation and maintenance of geothermal plants and fields.

The guides will be disseminated during the first quarter of 1993 at four workshops with the participation of 21 countries of Latin America and the Caribbean. One of these workshops will be intended for energy sector planners in the public institutions or ministries of these countries.

Source: IGA News 10-12/91

\section{ANNUAL GRC MEETING HELD IN SAN DIEGO, CALIFORNIA}

In October 1992, 470 members of the geothermal industry attended the Geothermal Resources Council's annual meeting in San Diego, California. The meeting provided a forum for the exchange of information regarding the latest trends and technical developments in the industry. In addition, vendors of goods and services to the industry exhibited their wares at the meeting.

Technical papers were presented in the following categories: Natural Hazards and Geothermal Development; Fractured Reservoirs; Economics and Regulation; Production Technology; Exploration; Reservoir Engineering; Power Plant Production and Reliability; Geology and 
Geochemistry; Geothermal Scaling, Corrosion and Drilling; Hot Dry Rock; Exploration Geophysics; and Direct Use.

Short courses preceding the meeting covered three topics: TETRAD Geothermal Reservoir Simulation (see FEDERAL BEAT), Geothermal Heat Pump Applications and Economics, and How To Make Your Project Financeable.

A number of attendees participated in two field trips after the meeting. Field Trip
No. 1 covered the geology of the Mexicali and Imperial Valleys. It included stops at the Imperial Fault, Salton Sea Scientific Drilling Project Salton Sea Mud Pots, Red Hill Volcano, Unocal Unit \#3, Goldfields Mesquite Mine, Algodones Dunes Overlook, Cerro Prieto Volcano, and Cerro Prieto geothermal field. Field Trip No. 2 covered geothermal power plants of the Mexicali and Imperial Valleys. The trip included tours of the Cerro Prieto geothermal field, Ormesa II plant, Heber plant, Unocal Units $\# 1$ and \#2, and the Magma Leathers plant.

\section{MAJOR SOURCES OF GEOTHERMAL INFORMATION}

This section of the GPM presents a representative sample of geothermal literature which has been reported since the last issue. Wider coverage of the literature may be found in a bimonthly publication of current abstracts entitled "Geothermal Energy" published by DOE's Office of Scientific and Technical Information. This publication may be obtained from the National Technical Information Service, Springfield, VA, 22161 as PB 88-914700. The annual subscription price for six issues is $\$ 90.00$ (domestic) and $\$ 180.00$ loutside the North American continent). This publication typically lists each separate paper, article, or report derived from another publication, such as conference proceedings, as a separate entry. Space does not permit separate listings in the GPM; thus the following are recommended:

Geothermal Resources Council Bulletin

Monthly Publication of GRC

P.O. Box 1350

Davis, California $95617-1350$

Geothermal Resources Council Transactions, Proceedings, GRC Annual Meetings.

Stanford University Annual Workshop on

Geothermal Reservoir Engineering

Stanford Geothermal Program

Dept. of Petroleum Engineering

Stanford, California 94305 
Proceedings of the Annual Geothermal Program Review Geothermal Division, U.S. Department of Energy

Available from the National Technical Information Service

U.S. Department of Commerce

Springfield, Virginia 22161 (No. IX March 19-21, 1991; No. X March 24-26, 1992)

Annual Geothermal Energy Program Summary,

Volumes 1 and 2, U.S. Department of Energy

The Geothermal Hot Line

California Division of Oil and Gas

$801 \mathrm{~K}$ Street, 20th Floor

Sacramento, California 95814-3530

Geothermics International Journal of Geothermal

Research and Its Applications

Pergamon Press Inc. Maxwell House Fairview Park

Elmsford, New York 10523

American Society of Mechanical Engineers

Energy Sources Technology Conference and Exhibition

Houston, Texas (January 26-30, 1992)

Journal of Heat Transfer

Transactions of the American Society of Mechanical Engineers

Series C

American Mineralogist

1992 Society of Petroleum Engineers Drilling Conference, New Orleans (February 18-21, 1992).

Lawrence Berkeley Laboratory

Earth Sciences Division

Annual Report 1990, OSTI; NTIS; INIS. Order No. DE92000647 (June 1991).

Eleventh SPE Symposium on Reservoir Simulation, Anaheim, California,

Society of Petroleum Engineers Technical Paper SPE21788 (February 17-20, 1991).

The Gulf and Peninsula Province of the Californias, American Association of Petroleum Geologists (1991). 
NOTE: Copies of the publications listed below should be obtained from NTIS at the address provided at the beginning of this chapter, or from one of the other sources listed. Those marked "GPO Dep." are available for inspection or interlibrary loan at Government Printing Office regional depository libraries. DOE and DOE contractors may order from the DOE Office of Scientific and Technical Information (OSTI), P.O. Box 62, Oak Ridge, TN 37831. The "GPO Dep. Order No." is the accession number for all locations; where an NTIS number is given it is a price code based on number of pages of hard copy and/or length of microfiche. ITIS is the Integrated Technical Information System maintained by OSTI for contractor accession to DOE online data bases.

\section{RESOURCE STATUS AND ASSESSMENT}

Thurston, G.C. and M.M. Plum. The Feasibility of Hydraulic Energy Recovery from Geopressured-Geothermal Resources, EG\&G Idaho Inc., OSTI; NTIS; GPO Dep. Order No. DE92003360 (Sept. 1991).

Propp. W.A., et al., Feasibility Study: Application of the Geopressured-Geothermal Resource to Pyrolytic Conversion or Decomposition/Detoxification Processes, OSTI; NTIS; GPO Dep. Order No. DE92003362 (Sept. 1991).

Ripperda, M., et al., The Ahuachapan Geothermal Field, El Salvador: Exploitation Model, Performance Predictions, Economics Analysis, Lawrence Berkeley Laboratory, OSTI; NTIS, GPO Dep. Order No. DE92000708 (May 1991).

Ripperda M., et al., The Ahuachapan Geothermal Field, El Salvador: Exploitation Model, Performance Predictions, Economics Analysis, Ibid., DE92000709.

Tengyel, M. and F. Bohoczky, "Geothermal Energy Resources in Hungary," International Journal of Ambient Energy, (United Kingdom); 12: No. 3 (July 1991).

Amistoso, A.E., et al., Reservoir Analysis of the Pallnpinon Geothermal Field, Negros Oriental, Philippines, Philippine National Oil Co., Lawrence Berkeley Laboratory, OSTI; NTIS; INIS Order No. DE92000647 (June 1991 ).

Sekioka, M., "Potential of Installed Thermal Power for Direct Uses of Geothermal Energy in Japan," Energy Sources; 14: No. 1 (1992).

Faulder, D.D. and M. Shook, "Geothermal Reservoir Simulation on Microcomputers," SPE Computer Applications, Society of Petroleum Engineers (July 1991). 
Thain, I.A., "1985-1990 Update Report on the Existing and Planned Utilization of Geothermal Energy for Electricity Generation in New Zealand," Energy Sources; 14: No. 2 (April-June 1992).

Haraden, J., "The Status and Potential Development of Magma Power," Energy, Oxford, United Kingdom; 17: No. 6 (June 1992).

Cambel, A.B. and J.E. Mock, "Iterated Function Systems for Geothermal Energy Exploration," Ibid.; No. 5 (May 1992).

Chesterman, C.W. and F.J. Kleinhampl, "Travertine Hot Springs, Mono County, California," California Geology, California Division of Mines and Geology; 44: No. 8 (Aug. 1991).

Papike, J.J., et al., "Geochemistry and Mineralogy of Fumarolic Deposits, Valley of Ten Thousand Smokes, Alaska: Bulk Chemical and Mineralogical Evolution of Dacite-rich Protollth," American Mineralogist; 76: No. 9-10 (Sept.-Oct. 1991).

\section{GEOLOGY AND HYDROLOGY OF GEOTHERMAL SYSTEMS}

Louisiana Geological Survey, Technical Support for Geopressured-Geothermal Well Activities in Louisiana, OSTI; NTIS; GPO Dep. Order No. DE91016295 (July 1991).

Pruess, K., TOUGH2: A General-Purpose Numerical Simulator for Multiphase Fluid and Heat Flow, OSTI; NTIS; GPO Dep. Order No. DE92000755 (May 1991).

Heiken, G., et al., "The Valles Toledo Caldera Complex, Jemez Volcanic Field, New Mexico," Annual Review of Earth and Planetary Sciences, Palo Alto, CA, Annual Reviews Inc. (1990).

O'Connell, D.R.H. and L.R. Johnson, "Progressive Inversion for Hypocenters and P Wave and S Wave Velocity Structure: Application to The Geysers, California, Geothermal Field," Journal of Geophysical Research, 96; No. B4 (April 10, 1991).

Manahan, J.H. and D.E. Condon, Coso Monitoring Program, October 1989 through September 1990. Technical Publication, 1 Oct. 89 - 30 Sept. 90, Comarco, Inc., Weapons Support Division, Ridgecrest, CA, (AD-A-238396/6 XAB) NTIS Prices: PC AO7/MFA02 (Jan. 1991 ).

Gosnold, W.D., Jr., Stratabound Geothermal Resources in North Dakota and South Dakota, North Dakota University, Energy and Environmental Research Center, OSTI; NTIS; GPO Dep. Order No. DE92003401 (Aug. 1991). 
Wooldridge, A.L, et al., "Magnetic Properties and Opaque Mineralogy of Rocks from Selected Seafloor Hydrothermal Sites at Oceanic Ridges," Journal of Geophysical Research - 95: No. B8 (Aug. 10, 1990).

Gosnold, W.D., "Heat Flow in the Great Plains of the United States," Ibid., 95: No. B1 (Jan. 10, 1990).

Chu, Min H., Study of the Geothermal Production Potential in the Williston Basin, North Dakota, North Dakota University, Energy and Environmental Research Center, OSTI; NTIS; GPO Dep. Order No. DE92006630 (Sept. 10, 1991).

Chu, T.Y., "Thermal Convection with Large Viscosity Variation in An Enclosure with Localized Heating," Journal of Heat Transfer, (Transactions of the Americas Society of Mechanical Engineers, Series C), 112: No. 2 (May 1990)

Chesley, J.T., et al., "Samarium-neodymyum Direct Dating of Fluorite Mineralization," Science; 252: No. 5008 (May 17, 1991).

Weir, G.J. and R.M. Young, "Quasi-steady Vertical Two-Phase Flows in Porous Media," Water Resources Research; 27: No. 6 (June 1991).

\section{GEOTHERMAL EXPLORATION AND EXPLORATION TECHNOLOGY}

Von Damm, K.L., "Seafloor Hydrothermal Activity: Black Smoker Chemistry and Chimneys," Annual Review of Earth and Planetary Sciences, Palo Alto, CA, Annual Reviews Inc. (1990).

Aunzo, Z.P., et al., Wellbore Models GWELL, GWNACL, and HOLA: Uşer's Guide, Lawrence Berkeley Laboratory, OSTI; NTIS; GPO Dep. Order No. DE92009494 (Octo. 1991).

Bender-Lamb, S., "Magma Energy Exploratory Well, Long Valley Caldera, Mono County, California," California Geology, California Division of Mines and Geology; 44: No. 4 (April 1991).

Wannamaker, P.E., Tensor Controlled-source Audiomagnetotelluric Survey Over the Sulphur Springs Thermal Area, Valles Caldera, Utah University Research Institute, Earth Science Laboratory, OSTI; NTIS; GPO Dep. Order No. DE92010950 (Oct. 1991).

Mueller, R.J., et al., "Possible Tectomagnetic Effect Observed from Mid-1989 to Mid-1990 in Long Valley Caldera, California," Geophysical Research Letters, American Geophysical Union; 18: No. 4 (April 1991). 
Fournier, R.O., "The Transition from Hydrostatic Fluid Pressure in Presently Active Continental Hydrothermal Systems in Crystalline Rock," Ibid; 18: No. 5 (May 1991).

Griston, S. and F.L. Cire, "Method for Determining a Transit Time for a Radioactive Tracer," U.S. Patent 5,072,387/A/, issued to Chevron Research and Technology Co., Patent and Trademark Office, Box 9, Washington, DC 20232 (Dec. 10, 1991).

\section{ECONOMIC AND FINANCIAL ASPECTS}

U.S. DOE Energy Information Administration, Geothermal Energy in the Western United States and Hawaii: Resources and Projected Electricity Generation Supplies, Office of Coal, Nuclear, Electric, and Alternative Fuels, OSTI; NTIS; INIS; GPO; GPO Dep. Order No. 92000614 (Sept. $1991)$.

National Renewable Energy Laboratory, Geothermal Energy Program Overview, OSTI; NTIS; GPO Dep. Order No. 91002172 (Dec. 1991).

Sifford, A. and K. Beale, Economic Development in Deschutes County, Oregon, Oregon State Department of Energy, OSTI; NTIS; INIS; GPO Dep. Order No. DE 92011095 (Dec. 1991).

Sifford, A. and K. Beale, "Economic Impacts of Geothermal Development in Harney County, Oregon," Ibid., DE 92011096.

United States Geothermal Industries Corp., "Report on a Mission to the Philippines Regarding the Opportunities for Private Investment in Geothermal Power Generation," prepared in cooperation with Bechtel National Inc. for U.S. Agency on International Development, Office of Energy, NTIS Prices: PC A03/MF A-01, INIS (Dec. 1990).

\section{ENVIRONMENTAL ASPECTS AND WASTE DISPOSAL}

Barbier, E., Geothermal Energy; Its Roles in the Generation of Electricity and Its Environmental Impact, International Institute for Geothermal Research, Pisa, Italy, National Research Council, OSTI; NTIS (US Sales Only); INIS Order No. DE 92607903 (CONF-910506-) (Sept. 1991 ).

New Energy Development Organization, Introductory Survey for a Long-Term Environment Monitoring Related to Geothermal Energy Development (Wild Animals), Tokyo, Japan, OSTI; NTIS (US Sales Only); Order No. DE 92769384 (March 1991).

Ibid., Data Sheets, DE92769385. 
Sorey, M.L., Effects of Potential Geothermal Development in the Corwin Springs Known Geothermal Resources Area, Montana, on the Thermal Features of Yellowstone National Park. Water Resources Investigation, US Geological Survey, Water Resources Division, (USGSMRI91-4052), NTIS Prices: PC A10/MFA03; INIS (1991).

Zorpette, G., "Hawaii's Geothermal Program," IEEE Spectrum, Institute of Electric and Electronics Engineers; 29: No. 2 (Feb. 1992).

\section{GEOTHERMAL POWER PLANTS}

El-Hawary, M.E. and G.A.N. Mbamalu, "Modeling the Incremental Cost and Water Conversion for Hydrothermal Coordination Studies," Electric Machines and Power System; 19; No. 3 (1991).

El-Hawary, M.E. and K.M. Ravindranath, "A General Overview of Multiple Objective Optimal Power Flow in Hydrothermal Electric Power systems," Ibid.

New Energy Development Organization, Investigation on Effective Promotion of Geothermal Energy Development, Tokyo, OSTI; NTIS IUS Sales only). Order No. DE 92783370 (March 19911.

Hammons, T.J., et al., "Geothermal Electric Power Generation in Iceland for the Proposed Iceland/United Kingdom HVD Power Link," IEEE Transactions on Energy Conversion, Institute of Electrical and Electronics Engineers; 6: No. 2 (June 1991).

Hawaii Natural Energy Institute, "Electrical Power Supply and Process Heat Supply Options," Hydrogen Energy from Renewable Resources, University of Hawaii at Monoa (1989).

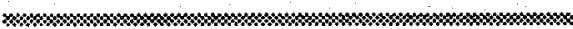

\section{GEOTHERMAL ENGINEERING}

Robertus, R.J., et al., "Particle Measurement and Brine Chemistry at the Salton Sea Deep Well," Pacific Northwest Laboratories, OSTI; NTIS; GPO Dep. Order No. DE 92000031 (Sept. 1991).

Bailey, T.F. and J.N. Strickland, "Geothermal Wellhead Repair Unit," U.S. Patent 4,984,636/A/, issued to Drilex Systems, Inc., Houston, TX, Patent and Trademark Office, BoX 9. Washington, D.C. 20252 (Jan. 15, 1991). 
Godare, W.L., "Geothermal Well Chemical Injection System," U.S. Patent 4,972,904/A/, issued to Foster Oilfield Equipment Co., Houston, TX (Nov. 27, 1990).

Lam, S.T., "Heat Extraction Modeling of Single-phase Sweep Flows in Fractured Geothermal Reservoirs," Stanford University, University Microfilms, P.O. Box 1764, Ann Arbor, MI 48106, Order No. 91-22,557 (1991).

Arellano, J., et al., "An Expert System Assisting Geothermal Reservoir Characterization," Expert Systems Applications for the Electric Power Industry, Hemisphere Publishing (1991).

Schroeder, R.C., "Analysis of Multi-feedpoint Geothermal Reservoirs," Proceedings of the SPE 1992 Western Regional Meeting. Society of Petroleum Engineers, Technical Paper SPE24073 (1992).

Wong, A. and T.A. Sudol, "Simulation of Thermal-well Sucker-rod Pumping," Production Engineering. Society of Petroleum Engineers; 7: No. 2 (May 1992).

Riney, T.D., "Depletion and Recovery Behavior of the Gladys McCall Geopressured Geothermal Reservoir," Energy Sources; 13: No. 4 (1991).

Gallup, D.L. and M.E. Obando, "Process for Controlling the pH of a Brine," U.S. Patent $5,085,782 / A /$ issued to Union Oil Co. of California, Patent and Trademark Office, Box 9 , Washington, D.C. 20232 (Feb. 4, 1992).

Gallup, D.L. and J.W. Jost, "Use of Reducing Agents to Control Scale Deposition from Hightemperature Brine," U.S. Patent 5,073,270/A/ issued to Union Oil Co. of California (Dec. 17, 19911.

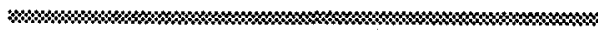

DIRECT ENERGY UTILIZATION

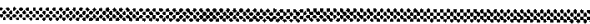

Maldonado, O., et al., Geothermal Demonstration: Zunil Food Dehydration Facility, Los Alamos National Laboratory, OSTI; NTIS; GPO Dep. Order No. DE91017467 (Aug. 1991).

California Office of Transportation Laboratory, "Evaluation of Geothermal Heating for Caltrans Facilities. Final Report 1988-1990," California State Department of Transportation REPT637358; NTIS Prices: PC A03/MF A01, PB-91-208348/XAB (June 1990).

Shapiro, C., The Use of Supercritical Fluid Processes for Detoxification of Pollutants Using Geopressured-Geothermal Fluids, EG\&G Idaho, Inc. (CONF-9110158-3), OSTI; NTIS; GPO Dep. Order No. DE92003323 (1991). 
Lunis, B.C., et al., The Feasibility of Applying Geopressured-Geothermal Resources to Direct Uses, EG\&G Idaho, Inc., OSTI; NTIS; GPO Dep. Order No. DE92003361 (Sept. 1991).

Lienau, P.J. and B.C. Lunis (eds.), Direct Use Engineering and Design, Geothermal Guidebook, Geo-heat Center, Oregon Institute of Technology, OSTI; NTIS; INIS; GPO Dep. Order No. DE92008686 (1991).

"Geothermal System Meets Space Heating Requirements." ASHRAE Journal, American Society of Heating, Refrigeration, and Air-Conditioning Engineers; 34: No. 3 (March 1992).

Rafferty, K. and G.M. Reistad, "Geothermal Energy," Heating, Ventilating, and AirConditioning Applications, American Society of Heating, Ventilating, and Air Conditioning (1991).

\section{GEOTHERMAL DATA AND THEORY}

Wood, R.H., Development of an Experimental Data Base and Theories for Prediction of Thermodynamic Properties of Aqueous Electrolytes and Nonelectrolytes of Geochemical Significance at Supercritical Temperatures and Pressures, Delaware University, Department of Chemistry and Biochemistry, OSTI; NTIS; GPO Dep. Order No. DE91018493 (May 2, 19911.

Williams, O., "Molten $\left(\mathrm{Mg}_{0.88} \mathrm{Fe}_{0.12}\right)_{2} \mathrm{SiO}_{4}$ at Lower Mantle Conditions," Geophysical Research Letters, American Geophysical Union (April 199).

Keeley, D.F. and J.R. Meriwether, "Aromatic Hydrocarbons Associated with Brines from Geopressured Wells," University of Southwestern Louisiana, Acadiana Research Laboratory, OSTI; NTIS; GPO Dep. Order No. DE92006450 (1989).

Cline, J.S., "Physical and Chemical Aspects of Fluid Evolution in Hydrothermal Ore Systems," Virginia Polytechnic Institute and State University, University Microfilms, P. O. Box 1764, Ann Arbor, Ml 48106, Order No. 91-09, 401 (1990).

Bebout, G.E., "Field-based Evidence for Devolatilization in Subduction Zones: Implications for Ore Magmatism," Science; 251; No. 4992, (Jan. 25, 1991).

Cole, D.R., Possible Evidence for Fluid-rock Oxygen Isotope Disequilibrium in Hydrothermal Systems, Oak Ridge National Laboratory, OSTI; NTIS; GPO Dep. Order No. DE92010641 (1992). 
Moeller, N. and J.H. Weare, UCSD Geothermal Chemical Modeling Project: DOE Advanced Brine Chemistry Program, California University, San Diego, Dept. of Chemistry, OSTI; NTIS; GPO Dep. Order No. 92013525 (April 1992).

Bowman, J.R. and J.D. Willett, "Spatial Patterns of Oxygen Isotope Exchange During Onedimensional Fluid Infiltration," Geophysical Research Letters, American Geophysical Union, 18: No. 5 (May 1991). 
U.S. Department of Energy

Geothermal Division, CE-122

1000 Independence Ave., S.W.

Washington, D.C. 20585

Phone (202) 586 - (ext.)

Robert L. San Martin

Roland R. Kessler

8089

John E. Mock

5340

Allan J. Jelacic

6054

David B. Lombard

4952

Stanley D. Calvert

8021

Raymond Fortuna

Gladys J. Hooper

1146

Raymond J. LaSala

4198

Lew W. Pratsch

1512

8076
Deputy Assistant Secretary Office of Utility Technologies

Director, Office of Renewable Energy Conversion

Director, Geothermal Division

Team Leader, Geosciences Research

Team Leader, Conversion Research

Manager, Direct Use

Manager, Geopressured Resources

Manager, Advanced Brine Chemistry, Hot Dry Rock, Long Valley Exploratory Well

Manager, Heat Cycle Research, Materials

Manager, Drilling Research, Geothermal Heat Pumps

Manager, Hydrothermal Reservoir Technology 
U.S. Department of Energy

Albuquerque Field Office

P. O. Box 5400

Albuquerque, NM 87112

U.S. Department of Energy

Golden Field Office

1617 Cole Boulevard

Golden, CO 80401

U.S. Department of Energy

Idaho Field Office

785 DOE Place

Idaho Falls, ID 83402
George P. Tennyson, Jr.

Senior Program Manager

(505) 845-4256

Nyles Lackey

Geothermal Project Manager

(505) 845-4257

Robert L. Martin

Geothermal Project Manager (303) 231-7663

Peggy Brookshier

Senior Program Manager

(208) 526-1403

Robert Creed

Geothermal Project Manager (208) 526-9063

NATIONAL LABORATORIES (GEOTHERMAL PRINCIPAL INVESTIGATORS)

Brookhaven National Laboratory

Process Materials Group

Building 526

Upton, NY 11973
Lawrence E. Kukacka

Advanced Materials Research

(516) 282-3065

Eugene T. Premuzic

Biochemical Processes

(516) 282-2893

Joel Renner

Idaho National Engineering Laboratory

P. O. Box 1625

Idaho Falls, ID 83415
Hydrothermal Reservoir Technology (208) 526-8824

Ben Rinehart

Geopressured Resources

(208) 526-1002

Greg Mines

Energy Conversion

(208) 528-0260 
Lawrence Berkeley Laboratory

Earth Sciences Division

Building 5OE

Berkeley, CA 94720

Los Alamos National Laboratory

P. O. Box 1663, MS-D443

Los Alamos, NM 87545

National Renewable Energy Laboratory 1617 Cole Boulevard

Golden, CO 80401

Sandia National Laboratoaries

P. O. Box 5800 , Division 6252

Albuquerque, NM 87185
Marcelo J. Lippmann

Reservoir Research

(510) 486-5035

David V. Duchane

Hot Dry Rock Research

(505) 667-9893

John V. Anderson

Energy Conversion

(303) 231-1022

James C. Dunn

Drilling R\&D; Long Valley Exploratory

Well; Geothermal Drilling Organization

(505) $844-4715$
STATE

NAME

ARIZONA

CALIFORNIA

COLORADO

HAWAII
Frank Mancini

Arizona Department of Commerce Energy Office

Solar and Energy Engineering

3800 North Central

Suite 1200

Phoenix, AZ 85012

Kelly Birkinshaw

California Energy Commission

1516 Ninth Street - MS-43

Sacramento, CA 95814

Andy Walker

Office of Energy Conservation

1675 Broadway \#1300

Denver, CO 80202-4613

Maurice H. Kava

Energy Program Administrator

Energy Division

335 Merchant Street, Room 110

Honolulu, HI 96813
PHONE NUMBER

Tel: $\quad$ (602) 280-1440

Fax: (602) 280-1445

Tel: (916) $654-4542$

Fax: (916) 654-4676

Tel: (303) $620-4292$

Fax: (303) 620-4288

Tel: $\quad(808) \quad 587-3812$

Fax: $(808)$ 587-3820 
Dean Nakano

State of Hawaii Geothermal Project Office 130 Merchant Street, Suite 1060

Honolulu, HI 96813

NEW MEXICO

NORTH DAKOTA

OREGON

UTAH
Chris Wentz

New Mexico Energy, Minerals and Natural Resources Department

2040 South Pacheco Street

Santa Fe, NM 87505

Joe Murphy

Program Administrator

Office of Intergovernmental Assistance

SECP/EES

State Capitol-14th Floor,

600 East Boulevard Ave.

Bismarck, ND 58505-01701

Alex Sifford

Oregon Department of Energy

625 Marion NE

Salem, OR 97310

John Solum

Utah Department of Natural Resources

Division of Water Rights

1636 West North Temple

Salt Lake City, UT 84116
Tel: (808) $586-2353 / 4$

Fax: $(808)$ 586-2536

Tel: (505) 827-5950

Fax: (505) 438-3855

Tel: (701) 224-2094

Fax: (701) 224-2308

Tel: $\quad$ (503) 378-2778

Fax: (503) 373-7806

Tel: (801) 538-7406

Fax: (801) $538-7315$

\section{STATE RESERVOIR ASSESSMENT PROGRAMS}

STATE

ALASKA
NAME

Roman Motyka

Department of Natural Resources

Division of Geological and

Geophysical Surveys

400 Willoughby Avenue

Juneau, AK 99801

Don Turner

University of Alaska

Geophysical Institute

Fairbanks, AK 99775-0800

Eugene Wescott

University of Alaska

Geophysical Institute

Fairbanks, AK 99775-0800

\section{PHONE NUMBER}

Tel: (907) 465-2520

Fax: (907) 586-3113
Tel: (907) 474-7576

Tel: (907) 474-7198

Fax: (907) 474-7290

Tel: $\quad$ (907) 474-7576

Tel: (907) 474-7198

Fax: (907) 474-7290 
CALIFORNIA

IDAHO

MONTANA

NEVADA

NEW MEXICO

OKLAHOMA

OREGON
Richard Thomas

California Division of Oil \& Gas

Tel: $\quad$ (916) 323-1787

Fax: (916) 323-0424

Geothermal Section

801 K Street, MS 21

20th Floor

Sacramento, CA 95814-3530

Rick Sterling

Tel: $\quad(208) 327-7900$

Fax: 1208 ) $327-7866$

Idaho Department of Water Resources

1301 North Orchard, Statehouse Mail

Boise, ID 83720

Montana Department of Natural

Tel: (406) 444-6697

Resources and Conservation

Energy Division

1520 6th Avenue, $E$

Helena, MT 59620-2301

Bill Sill

Hydrothermal Division

Montana College of Mineral

Science and Technology

Butte, MT 59701

Chuck Widemand

Hydrothermal Division

Montana College of Mineral

Science and Technology

Butte, MT 59701

Dennis Trexler

Division of Earth Science

100 Washington Street, Suite 201

Reno, NV 89503

Rudi Schoenmackers

Southwest Technology

Development Institute

New Mexico State University

P.O. Box 30001

Department 3-SOL

Las Cruces, NM 88003-001

Ken Luza

Oklahoma Geological Survey

University of Oklahoma

100 E. Boyd, Room N-131

Norman, OK 73019-0628

Tel: $\quad(406)$ 496-4209

Tel: (406) 496-4211

Tel: $\quad$ (406) 496-4209

Tel: (406) 496-4211

Tel: $\quad$ (702) 784-6151

Fax: (702) 784-4549

Tel: (505) 646-1846

Tel: (405) 325-3031

Fax: (405) 325-3180

Tel: (503) $731-4100$

Fax: (503) 731-4066

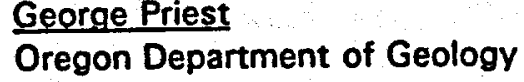

and Mineral Industries

800 NE Oregon Street, \#28

Suite 965

Portland, OR 97232 
UTAH

WASHINGTON
Robert Blackett

Utah Geological and Mineral Survey

2363 S. Foothill Drive

Salt Lake City, UT 84109

Eric Schuster

Department of Natural Resources

Division of Geology and Earth Resources

P.0. Box 47007

Olympia, WA 98504-7007
Tel: (801) $467-7970$

Fax: (801) 467-4070

Tel: (206) 902-1451

Fax: (206) 902-1785 